\title{
Identifying the link between lineament and cave passage trends to comprehend fractures continuity and influence on the Kinta Valley karst system, Peninsular Malaysia
}

\author{
Solomon Kassa ${ }^{1}$, Bernard J. Pierson ${ }^{2}$, Weng Sum Chow ${ }^{3}$ and Jasmi B. Ab. Talib ${ }^{4}$
}

\begin{abstract}
:
Kassa S., Pierson B., Chow W. S., Talib J.B. Ab. 2012. Identifying the link between lineament and cave passage trends to comprehend fractures continuity and influence on the Kinta Valley karst system. International Journal of Speleology, 41(1), 59-73. Tampa, FL (USA). ISSN 0392-6672. http://dx.doi.org/10.5038/1827-806X.41.1.7

The Kinta Valley karst landscape is characterised by residual limestone hills scattered all over the valley. The aim of this study is to ascertain the link between lineament and cave passage orientations, and to identify the main fracture controlling the karst features. To achieve that, standard cave surveying and direct lineament extraction techniques, from a $2.5 \mathrm{~m}$ resolution spot image, were employed. Six trends of lineaments were obtained from the remnant limestone hills, and their main orientation appears to be in the NNW-SSE. Similarly, various caves were surveyed and mapped; their passage orientation analyses reveal that NNW-SSE is the prominent direction. The similarity of the lineaments orientation and caves passage trend attests that the karst formation is controlled by the geological structures. Such a similar trend observed in all hills enabled to infer the orientation of the primary structure responsible for the formation of the extant karst features. The multi-fracturing episodes rendered the Kinta Valley to be structurally complex and the karst features unravelled this effect, as evidenced by features such as circular and sinuous cave passage morphology, which developed ensuing fractures oriented in different directions.
\end{abstract}

Keywords: cave passage; fracture; Kinta Valley; lineament; vestige hill

Received 26 July 2011; Revised 14 October 2011; Accepted 1 November 2011

\section{INTRODUCTION}

Karst is a special type of landscape which can be defined as a terrain with distinctive hydrology and landforms that arise from a combination of high rock solubility and well developed secondary porosity (Ford \& Williams, 2007). In many areas, joints with their regional pattern are the most important avenue of ground water movement (Deike, 1989), and they have a profound influence on the hydrology of karst regions as they host and guide almost all parts of the underground solution conduit networks that distinguish the karst system from others (Ford \& Williams, 2007).

Flow paths in karst are developed preferentially along fault zones, joints and bedding planes, and the presence of tectonic structures is considered indispensable for the development of karst (Glazek, 1989). The relation between structures and caves

\footnotetext{
${ }^{1}$ Universiti Teknologi PETRONAS, Bandar Seri Iskandar, 31750 Tronoh, Perak, Malaysia. (solkas4@gmail.com)
}

22(bernard_pierson@petronas.com.my)

${ }^{3}$ (chow_wengsum@petronas.com.my)

4(jasmi_atalib@petronas.com.my) development has previously been indicated by Deike (1969), Palmer (1975, 1989), Reeder et al. (1996), and Florea (2002). The distribution and geometry of structures control the original solutional shapes of the natural drainpipes that make up the conduit system (White and Deike, 1989). According to Jameson (2005), in order to study conduit evolution, structural segments should be identified and analyzed; he stated some primary conditions that should be fulfilled to identify early fracture conduits: (1) prominent fractures must be retained as fracture traces in bed rock passage perimeters, (2) fracture traces must be accessible within the cave with minimal covering, and (3) fracturing associated with later cave enlargement is minimal and distinguishable from transmissive fractures.

According to Bosák (2003 and reference therein), there are two generally accepted phases of speleogenesis: (1) initiation - initial enlargement of a fracture to a critical size, and (2) enlargement growth of a protoconduit to full conduit size. In the case of metamorphosed carbonate, only open fracture routes provide the opportunity for dissolution and enlargement into cave passages (Faulkner, 2006); however, void development is considered pre-tectonic, as it is favoured along inception horizons and commences during diagenesis (Lowe, 1999). Faulkner 


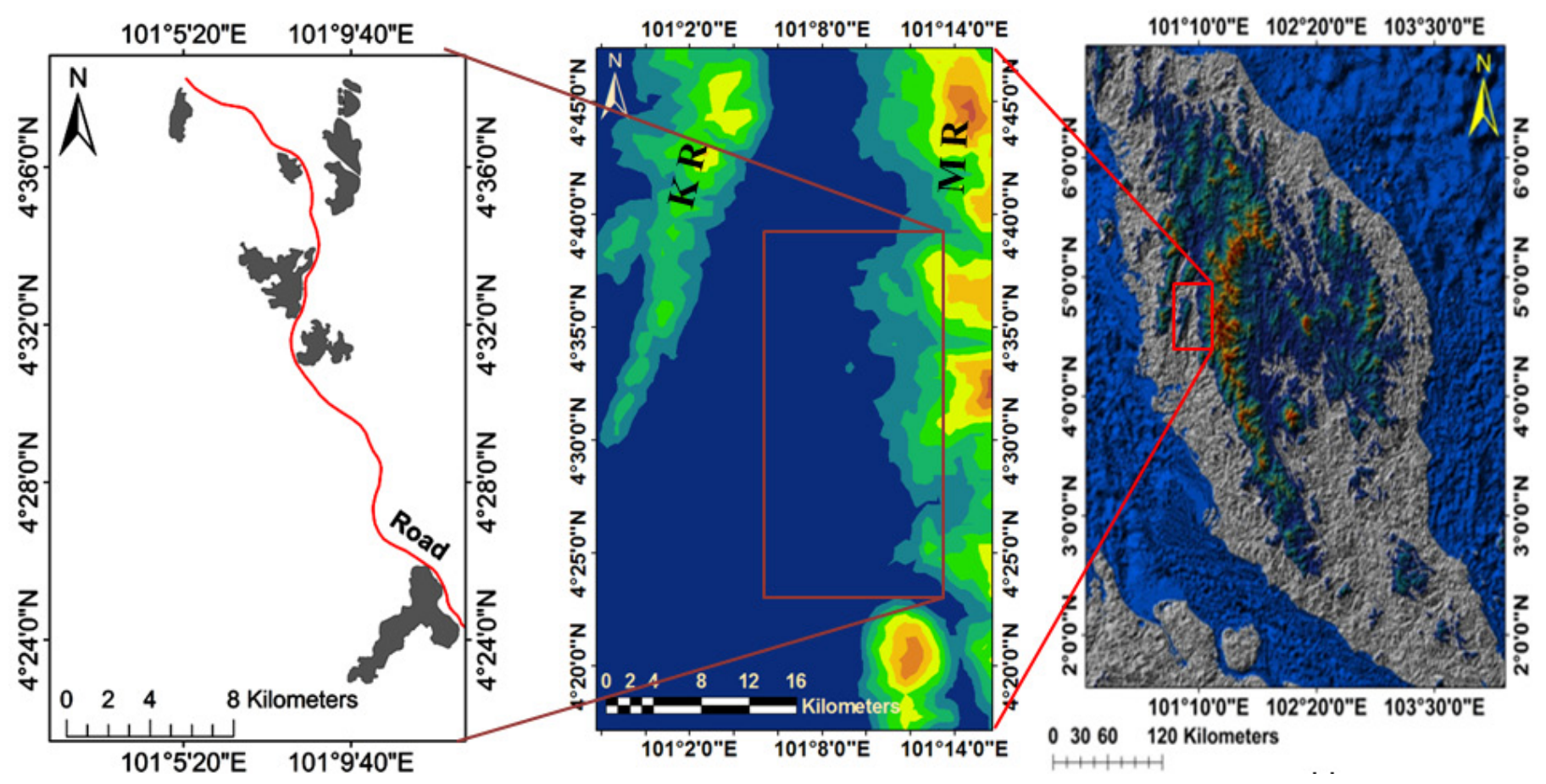

Fig.1. Location map of the study area indicating (a) the distribution of the major remnant hills mainly in the eastern part of the valley, (b) the Kinta Valley bounded by granite ranges and (c) Peninsular Malaysia

(2006) indicated that the solutional karst caves of the Caledonide marbles were initiated by tectonic inception, in contrast to inception horizons (Lowe, 1999), as the metamorphosed carbonate is typified by the lack of (1) primary porosity, (2) stratigraphic horizons, and (3) regional-scale systems.

The general term "lineament" is applied to all linear features seen on aerial photographs and images (Spencer, 1988). To analyze the relation between geological structures and karst features, extraction of lineaments should be made from satellite images, which afford a large areal coverage. Aerial photography has been the most widely used form of remote sensing, and lineament interpretations from them were common; however, as the resolution of satellite images continued to improve, they replaced aerial photographs for a variety of remote sensing applications (Lillesand et al., 2008). Image processing techniques have previously been used to extract lineaments from satellite images as a means of identifying linear surface traces of geologic structures such as faults and joints (Mah et al., 1995; Henderson et al., 1996; Süzen \& Toprak, 1998; Arlegui \& Soriano, 1998; Leech et al. 2003; Nama, 2004). As geological structures serve as good path ways for subsurface water circulation, the recognition of lineaments on satellite images has proved to be very useful for the exploration of groundwater (Sander et al., 1997; Tam et al., 2004; Galanos et al., 2006). Moreover, identifying lineaments and pinpointing zones of maximum occurrence, based on density indices, is important in predicting possible sites of cave occurrences (Hung et al., 2002).

Cave survey is indispensable to identify general cave passage trends, and to comprehend the main controlling factors for their development. Comparing caves passage orientations with lineament trends, extracted from the hills hosting the caves, is essential to recognize the influence of geological structures on karst development. The aim of this work is to study the impact of fracturing on the development of karst in the Kinta Valley, and to pinpoint the most intrinsic features that attest to this phenomenon. The following questions will also be addressed: (i) Is it possible to identify which trend of structures formed first and was mainly responsible for the commencement of karstification? (b) Are the different caves located in the scattered hills influenced by the same structure? (c) As a matured karst system, is there any evidence of multi-fracturing imprinted on the karst features?

Henceforth, some common local terms such as Gunung (hill) and Gua (cave) will be used in the text.

\section{STUDY AREA}

Peninsular Malaysia is bounded by $1^{\circ} 20^{\prime} \mathrm{N}$ to $6^{\circ} 40^{\prime} \mathrm{N}$ latitude and $99^{\circ} 35^{\prime} \mathrm{E}$ to $104^{\circ} 20^{\prime} \mathrm{E}$ longitude. The study area, Kinta Valley, is situated in the western part of peninsular Malaysia (Fig. 1). It is bordered by two granitic ranges; the Klendang Range (KR) and the Main Range (MR) in the west and east, respectively, and is characterized by remnant hills which steeply stand and stick out of the alluvium deposit that covers the valley. According to Geyer et al. (2005) some 47 steep isolated limestone hills that rise up to $600 \mathrm{~m}$ are present in the area. These hills are located mainly in the eastern part of the valley, and the highest and longest ones are indicated in Figure 1a, but the rest appears too small to depict on the map though most of them are situated in the eastern part. They are the vestige of an expansive limestone bedrock which has been dissolved/degraded away. 

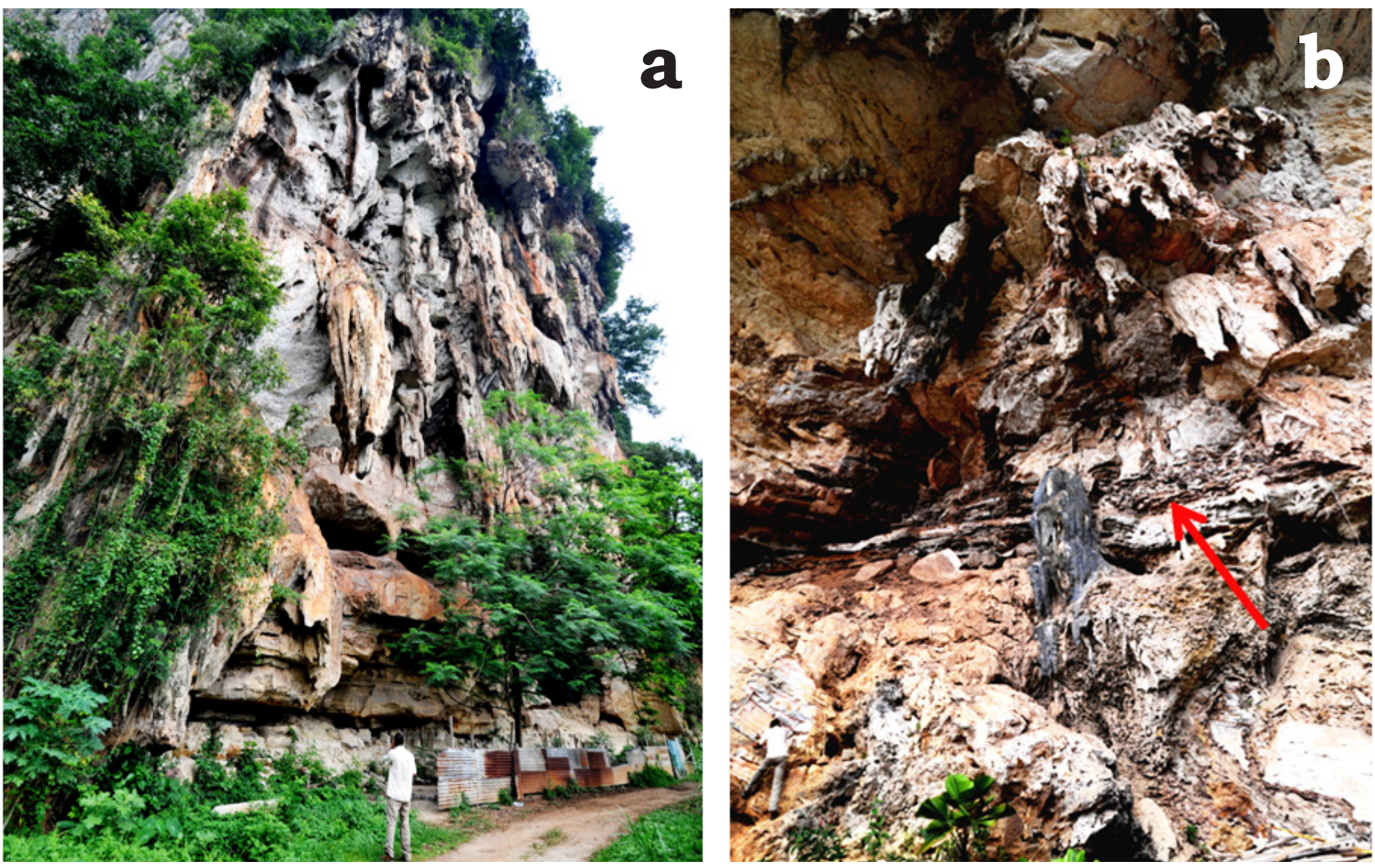

Fig.2. (a) Stalactites at the face of the precipitous hill depicting the pre-existence of a cave before it collapsed, and (b) Horizontally layered fine sediment (red arrow) located before the entrance of Kek Lok Tong Cave indicating the collapse of part of this cave

The Kinta Valley has an elongated shape which is about $50 \mathrm{~km}$ long and $8-21 \mathrm{~km}$ wide; the valley gets wider towards the south. The limestone hills which dot the valley are presumed to be of CarboniferousPermian age (Ingham \& Bradford, 1960) or Silurian to Permian (Peng, 2009 and reference therein), and are at an extreme stage as typified by their riddled karstic caves and dolines.

\section{Karst morphology}

The extensive dissolution of the carbonate rock in the Kinta Valley has led the development of various karstic features, such as tower karst, dolines, caverns, caves, and pinnacles, in some places. They are the result of both allogenic waters, derived from the adjoining granite hills, and autogenic waters, originated from percolating rainwater. There are many

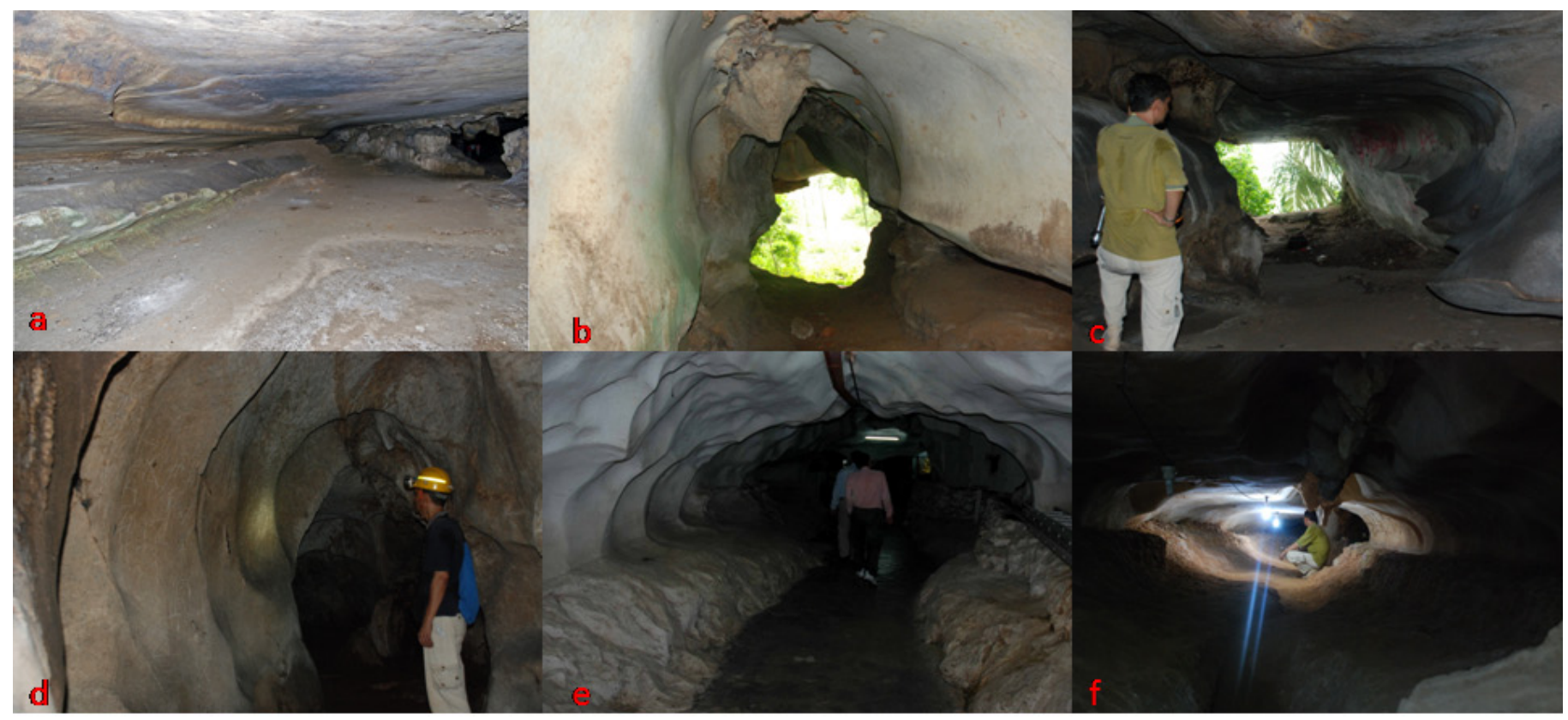

Fig.3. Various relict caves passage morphology depicting their formation in phreatic condition. They are part of the cave (a) Masoora, (b) Angin, (c) Kapayang, (d) Lyang Lyang, (e) Sam Poh Tong, (f) Wat Tat Fook 


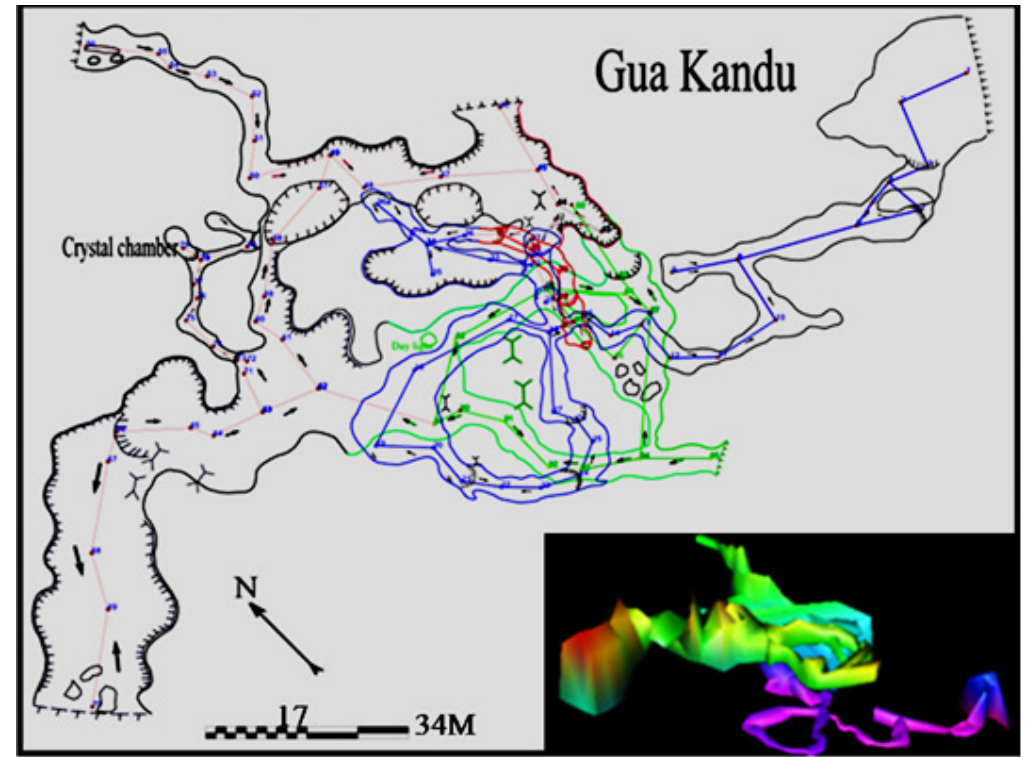

(a)

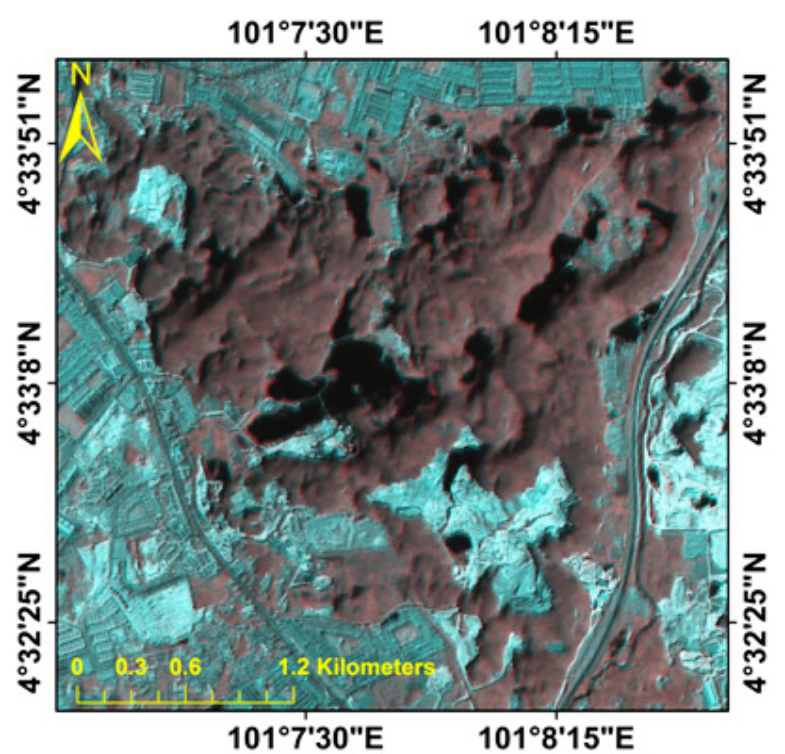

(b)

Fig.4. (a) multi-levelled Kandu cave (plan view) and the inset 3D view, and (b) Image of Gunung Rapat depicting intense pitting with dolines

rivers which arise from the bounding Main Range granite and drain southwest via the Kinta Valley karst region; including Raya River, Pari River, Penjih River, Dipang River and Kampar River (Fig. 8), which played a crucial role in the development of the extant karst morphology of the area. Because of the tremendous dissection caused by these rivers, the western part of the area is typified by very isolated tower karsts with caves formed at the foot of these towers, compared to the eastern part which is characterised by relatively clustered towers and caves occurring 10-15 $\mathrm{m}$, in most places, above their base. At the base of the steepsided hills, horizontal grooves or notches which might have been formed by ground water or river action or stagnant swamps are noticeable.

The caves located in the vestige hills are very small, $60 \mathrm{~m}$ to $1.5 \mathrm{~km}$ long, and typified by relatively big chambers, 30-60 m wide with vertical range up to 100 $\mathrm{m}$. Most of the caves appear to be part of a previously long cave, before collapse, as the stalactites hanging on the faces of the precipitous hills (for example, Fig. 2a) suggest. These stalactites are very stiff and vertically grown ones, unlike those which form on the surface, i.e. after collapse, and where they were observed cave infilling sediments, for instance at the base of the overhang (Fig. 2b) near Kek Lok Tong cave, were conspicuous. These sediments are the same as those observed inside the adjoining uncollapsed cave, further attesting to the pre-existence of a long cave.

In the study area, the caves are of two types: (i) Relict Caves, related to an earlier hydrologic system, which are relatively very small compared to the (ii) Modern (River) Caves. The morphology of most of the surveyed relict caves suggest their formation in phreatic condition (Fig. 3), as the smooth wall and ceiling, and the circular to oval shape of the passage depict; their linear trend, most likely, is a result of primary conduit development via fractures. The

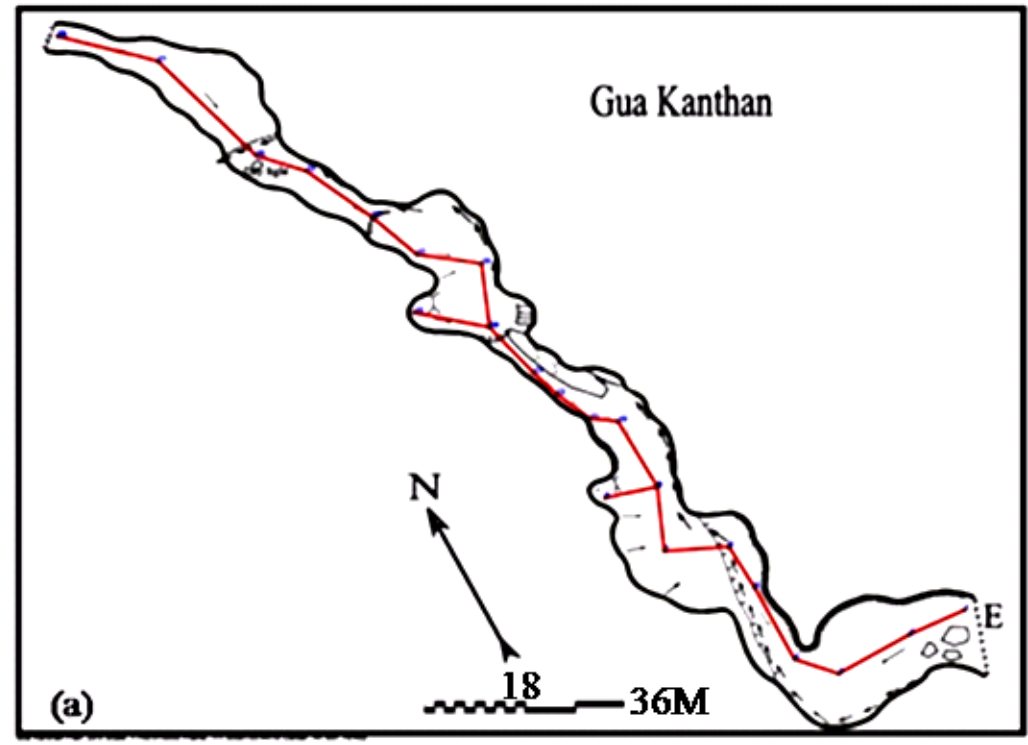

Fig.5. Map of (a) Kanthan river cave and (b) relict Paradise Valley cave.

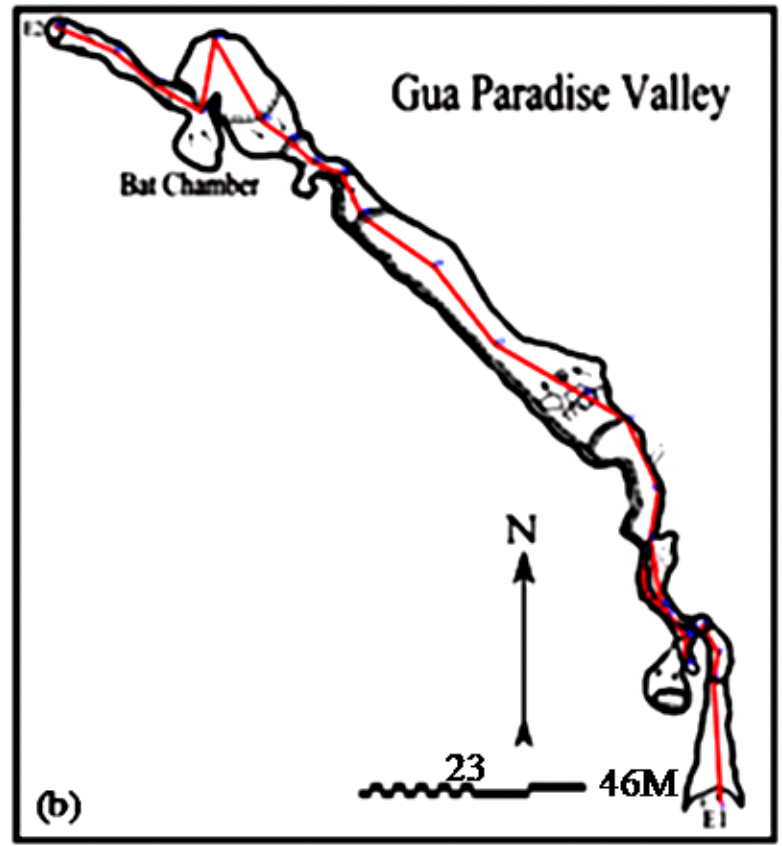




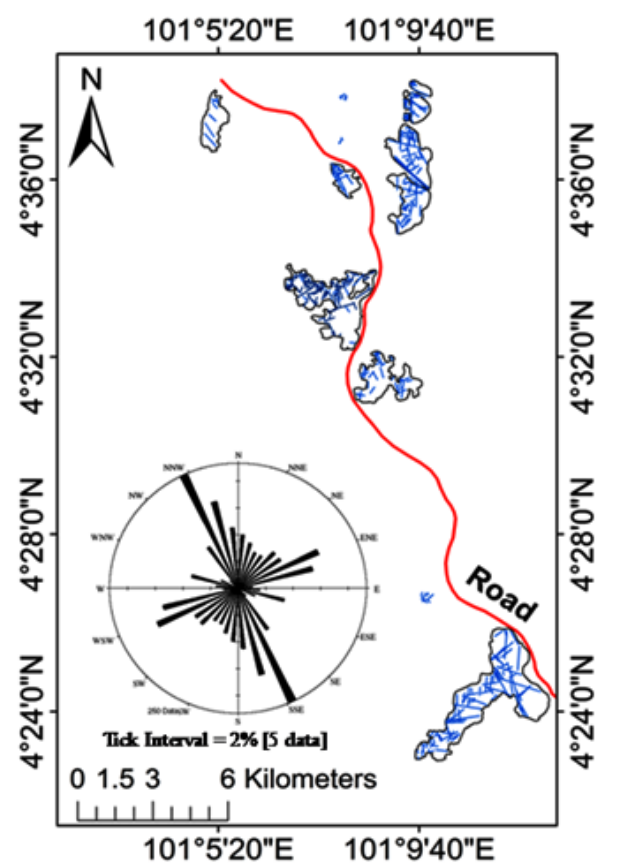

(a)

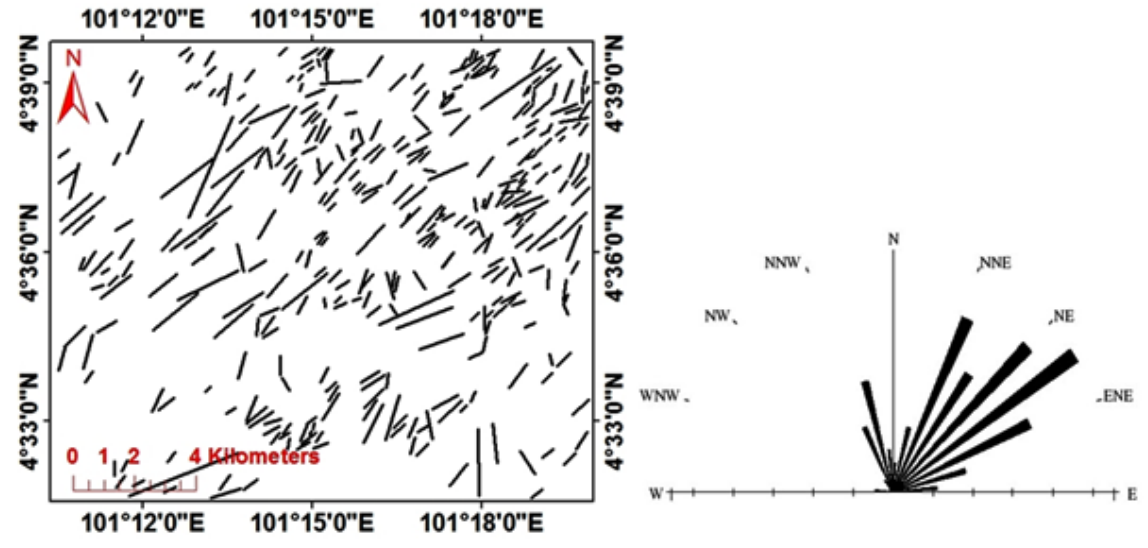

(b)

Fig.6. (a) overall distribution of lineaments in the remnant hills \& the inset rose diagram depicting their general trend, (b) Lineaments from part of the Main Range Granite which adjoins the vestige hills and associated rose diagram indicating their trend

morphology of the caves' passage, besides illustrating their formation in phreatic conditions, clearly indicates their modification by running waters as sediments deposited along the passages are conspicuous. Collapsed caves, multilevel passages (Fig. 4a), hills pitted with dolines (Fig. 4b) and honeycombed with caves (for example only in one hill 'Gunung Lanno' 32 caves were surveyed by Geyer et al., 2005), which are clear indicators of the consequence of intense karstification, are characteristic karstic features of the area.

Although small caves characterised by collapsed passages are common, relatively narrow and linear caves, such as Gua Kanthan (Fig. 5a) and Gua Paradise Valley (Fig. 5b), whose prominent passage trend plainly corresponds with the main lineament trend extracted from the vestige hills (Fig. 6a), are also evident in the area. And the distribution of the surveyed caves also appears somewhat aligned in the same trend (Fig. 7a). In general, the karst landform in the Kinta Valley seems to have aligned in the same orientation as the peninsula whose shape is believed to be controlled by the regional structures (Shuib, 2009). The overall proportion or areal extent of the vestige hills is about $32.89 \mathrm{~km}^{2}$ whereas the Valley, which once was covered by the expansive limestone bedrock, covers approximately $1315.77 \mathrm{~km}^{2}$. The $2.5 \%$ areal coverage of the remnant hills attests that this karst region is at an extreme stage of karstification.

\section{GEOLOGICAL SETTING}

Southeast Asia is a geologically complex region that has evolved through various phases of continental accretion, mountain building and rifting. Malaysia occupies a central position in Southeast Asia such that its geological history is inextricably linked to that of the whole region (Madon, 1999).

The Peninsula has traditionally been subdivided in to three belts; Western, Central and Eastern belt (Metcalfe, 2000; Peng, 2009); the N-S to NNW-SSE structural grain is used for this division (Shuib, 2009). The main structural trend of the peninsula is NNW-SSE, and this general trend is superimposed by later N-S, NW-SE, NNE-SSW, and E-W major faults (Shuib, 2009).

In the Kinta Valley, the environment of deposition during the Palaeozoic time was predominantly clear, warm, shallow marine with occasional influxes of carbonaceous terrigenous sediments which gave rise to the consolidation of argillaceous lenses intercalated with the limestone (Ingham \& Bradford, 1960). However, a sequence of thinly bedded to laminated micritic limestone with abundant slumps and thin interbedded chert laminations is documented and interpreted to be deep marine slope deposits (Pierson et al., 2009). Later metamorphism resulted in the formation of schists, marbles and phyllites (Ingham \& Bradford, 1960); the metamorphism process is believed to be terminated in Late Jurassic (Hutchison, 1966).

The Main Range Granite, which adjoins the Kinta Valley carbonate and forms the backbone watershed mountain range of the Peninsula, is believed to be a result of several large granitic batholiths (Hutchison, 2007; Ghani, 2009). In the study area, the carbonate rocks are laterally bounded by Late Mesozoic granite plutonic rocks emplaced by activity related to Late Triassic uplift from plate boundary stresses along the western edge of the Malay Peninsula (Gillieson, 2005). The limestone, compressed by the granites (fig.7b), has been altered by contact metamorphism to marbles and skarn (Gillieson, 2005; Hutchison, 2007). Nonetheless, the effect of metamorphism diminishes away from the contact zone, as the eastern side, where the limestone-granite contact situated, is characterised by crystalline carbonate rocks whereas the western side is affected by slight metamorphism as it is typified by feebly crystalline rocks having clear sedimentary structure. Where the metamorphism effect is insignificant, sedimentary structures marked by thicker beds which occasionally interrupt the 


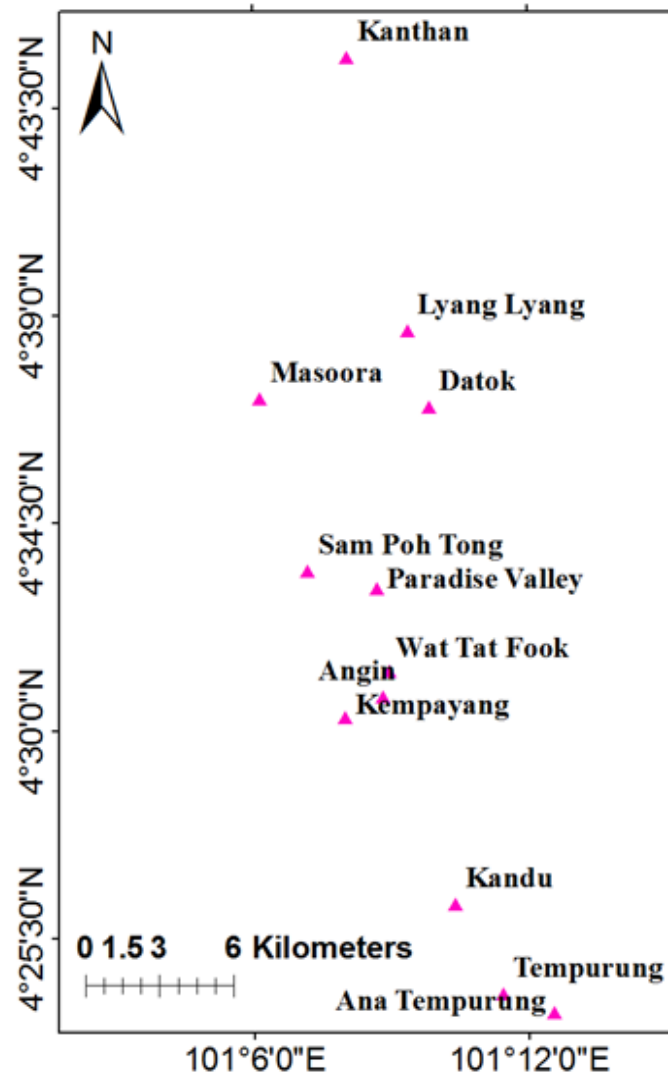

monotonous thinly bedded sequence, containing breccia beds and shallow marine fragments or fossils (Pierson et al., 2009), are conspicuous.

Ingham \& Bradford (1960) believed that most of the rock structures in the Kinta Valley were developed during the emplacement of the granite ranges during the late Mesozoic times. Similarly, Shuib (2009) indicated that the prominent regional structures are formed after or at the late stage of the emplacement of the Main Range Granite in the Late Triassic to Jurassic. The structure of the area is quite complex; it is probable that more than one phase of tectonics has affected the area in the past to bring about the present structural settings. Ingham \& Bradford (1960) recognised two types of faults: (a) shear faults, running parallel to the strike of the beds, and (b) tension faults that run obliquely across the valley. The complex structure of the area is believed to have invariably exerted its influence on the drainage pattern of the area.

\section{MATERIALS AND METHODS}

In order to identify the prominent direction of the cave passages, different caves were first surveyed by standard method of cave mapping using clinometers, compass and laser distance measuring instruments. After the survey data were edited and viewed in COMPASS (cave mapping software), final maps were generated using Inkscape (drawing software). Before indicating the orientations of the caves passage using graph tool (COMPASS), the following considerations were made: (i) minimum length of the survey line to be eight meter, since below this length considered to be not representative to depict prominent trend and (ii) the passage should be straight and not collapsed. After processing the input data in COMPASS, their trends were depicted using rose diagrams. The GEOrient software was used to produce a rose diagram which indicates the overall caves passage orientations.

Spot image, with a resolution of $2.5 \mathrm{~m}$, acquired in 2010 (path 268/row 341), provided by Malaysian Remote Sensing Agency (MRSA), was employed for the extraction of lineaments. There are two methods of extracting lineaments from satellite imagery: manual (visual interpretation) and automatic; for this study we used the former, as it is easier to manually identify geological elements from non geological ones.

There are various image enhancement techniques, based on the modification of images to optimize tonal and textural differences in images, which facilitate the visual interpretability of the images, including Principal Component Analysis (PCA), Filtering, Composite Color, and Contrast Stretch. Previously, many workers (Mah et al., 1995; Leech et al., 2003; Nama, 2004 , to mention a few) used one or a combination of these methods to enhance the interpretability of the images for the ultimate extraction of lineaments. In this study, two image enhancement techniques directional filtering and color composite were adapted. Directional filtering was conducted to enhance linear features in specific directions, and color composite, to achieve a maximum contrast by combining different bands (RGB), for the ease of identifying linear patterns of geological elements. According to Koike et al. (1998) and others, the basic method of identifying lineaments in an image are: straight stream and valley segments, systematic offset of rivers, continuous scarps and tonal anomaly, which are the consequence of geological structures. Hence, the lineaments were traced based on distinct tonal differences, shape and 
pattern. Image enhancement has been undertaken using PCI Geomatics software, and Arc GIS 9.3 used to digitize the lineaments and make the final map. Arc GIS 9.3 software was also used to extract the rivers and streams from topographic map of Ipoh (C2006.

Map of the Kinta Valley was made using xyz data obtained from Becker et al. (2009) and the area of the Kinta valley and the vestige hills were measured using PCI Geomatica software.

\section{RESULTS}

Figure 8 indicates the general SW trend of the allogenic waters denuding the Kinta Valley karst region. This flow orientation corresponds with the prominent lineaments trend extracted from the granite (Fig. 6b). Figure 9a $\&$ 9b illustrate the barbed nature of river caves where the linear and undulating flow direction may denote their formation following the incipient fracture traces.

Even though collapsed caves are common in the area, the rose diagrams in Figure 10a-j depict cave passage orientations for those possessing linear conduits, and Figure 10k indicates the overall passage trend for all caves. The rose diagrams in Figure 10a-i are made using the 180 degree rose which indicates that all angles greater than 180 are reversed and all passages that are on the same fracture line are grouped together. These diagrams clearly show that the prominent orientation for the caves passage is NNW-SSE. As Kandu cave is a multi level passage cave (Fig.4a), the rose diagram in Fig.10j depicts its passages trend at different levels, and N-S appears to be the main orientation.

The $2.5 \mathrm{~m}$ resolution spot image enabled us to easily identify and extract the lineaments. Figure $6 a$ indicates the overall lineaments trend in the Kinta valley, and it is quite noticeable that the structures are dominantly striking NNW-SSE. Lineaments are also extracted from part of the Main Range granite hill (Fig. 6b), which covers $271 \mathrm{~km}^{2}$ and adjoins the area where most of the vestige hills are located. As Figure $6 \mathrm{~b}$ depicts, the major strike orientation is NNE-SSW

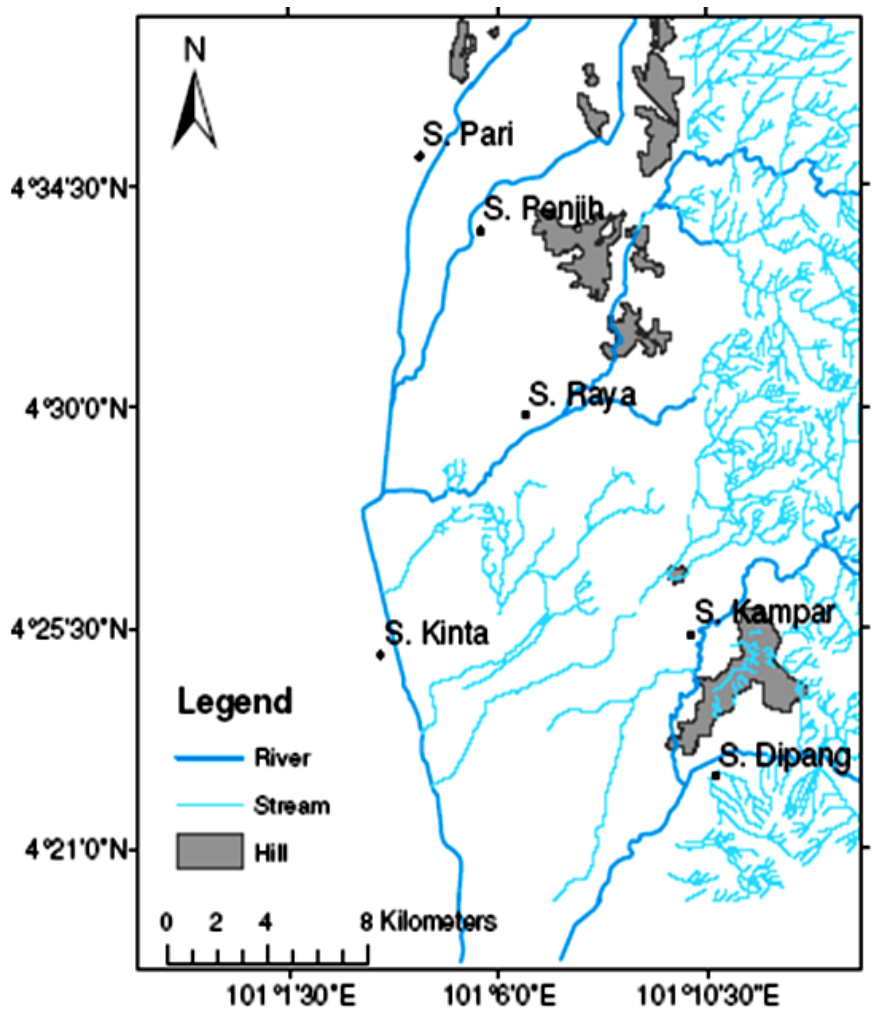

Fig.8. The major kinta river and its tributaries arising from the Main Range Granite and draining SW via the Kinta Valley karst region

to NE-SW, which is different from the major trends observed in the remnant hills. In general, six set of lineaments were observed from the vestige hills, and they appear to strike in the NNW-SSE, NW-SE, N-S, ENE-WSW, NNE-SSW, and WNW-ESE direction (Fig. 11a-e). Although they possess multi fractures, the associated rose diagrams denote most frequent trends. Ground truthing of the study site reveals that the NNW-SSE and NNE-SSW to NE-SW oriented structures are dominant. The high frequency of these structures can also be easily distinguished from a picture of a small doline (Fig. 12a) in Gunung Datok.

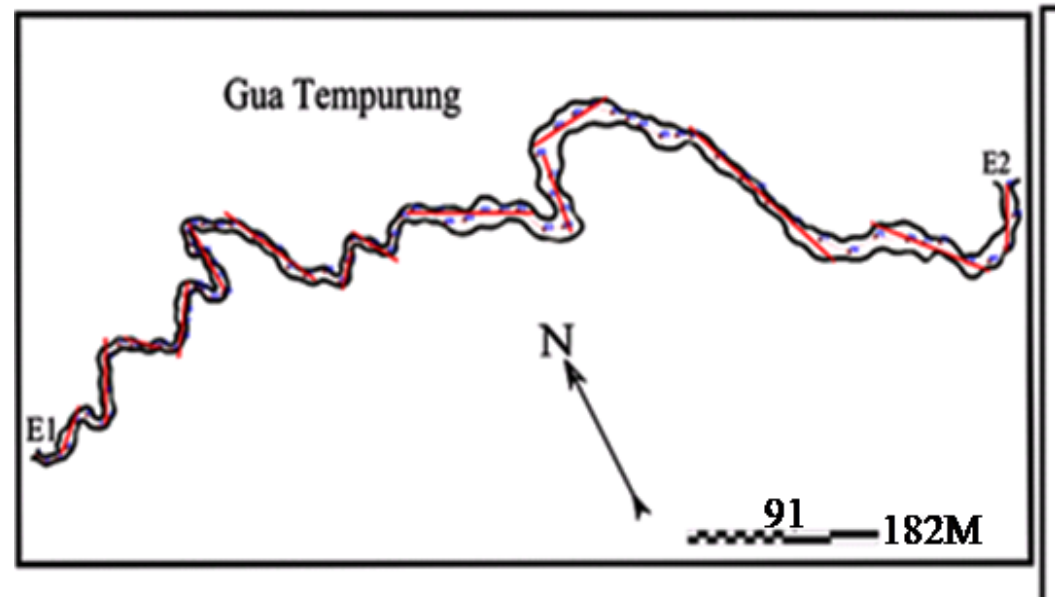

(a)

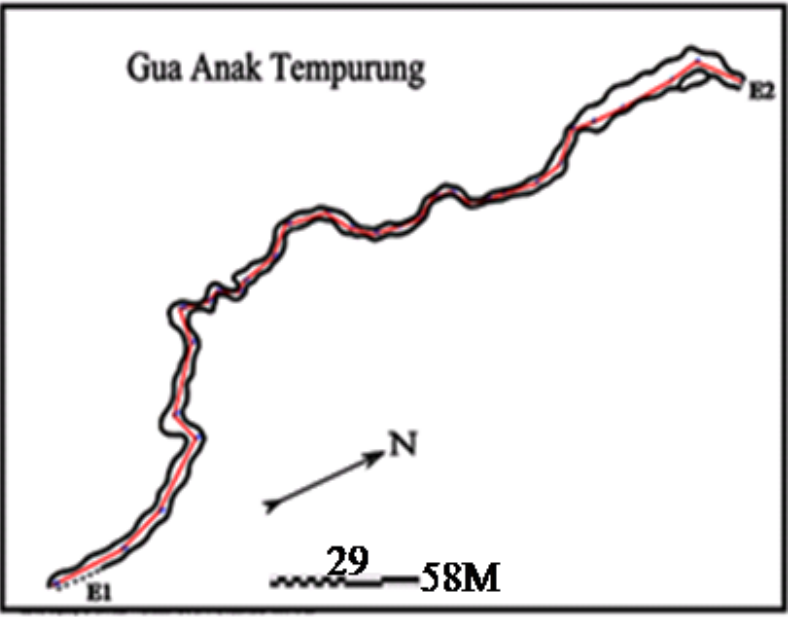

(b)

Fig.9. River caves located in Gunung Tempurung (a) Gua Tempurung and (b) Gua Anak Tempurung, depicting the impact of multi-fracturing for their convoluted passage. The red lines indicate the possible trend of fractures along which conduit development might have taken place. 


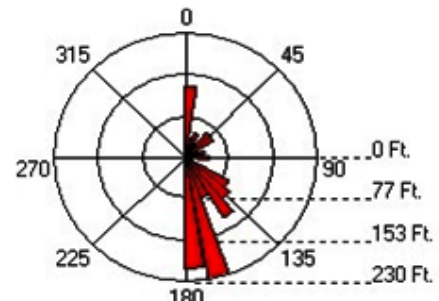

(a)

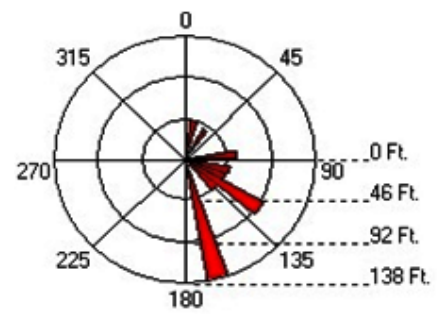

(e)

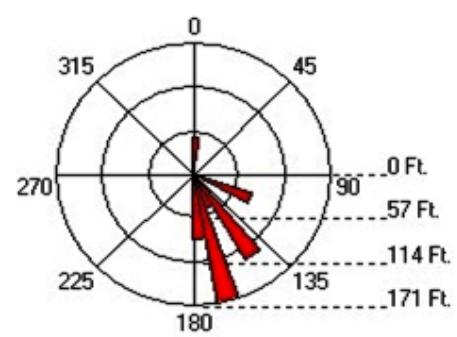

(i)

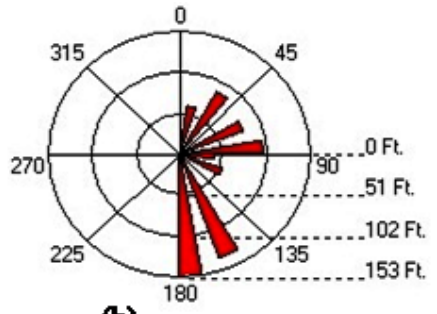

(b)

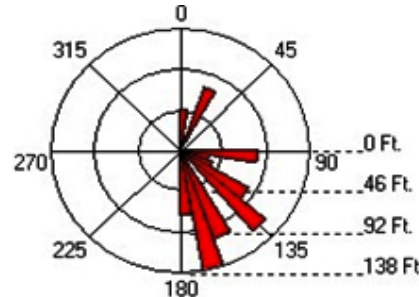

(c)

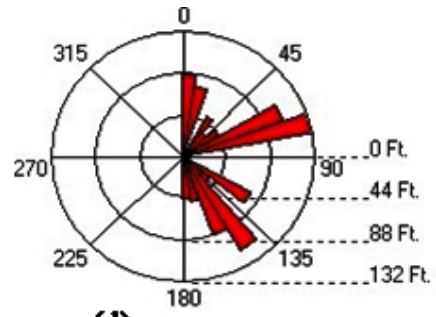

(d)

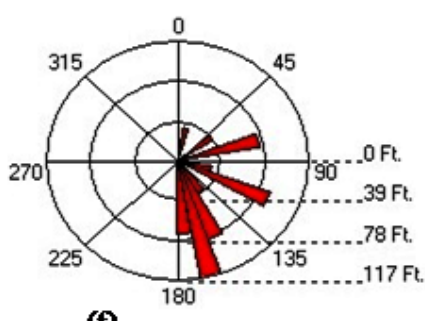

(f)

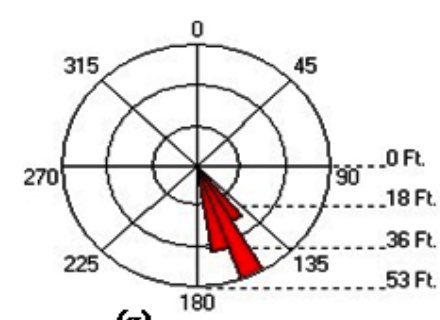

(g)

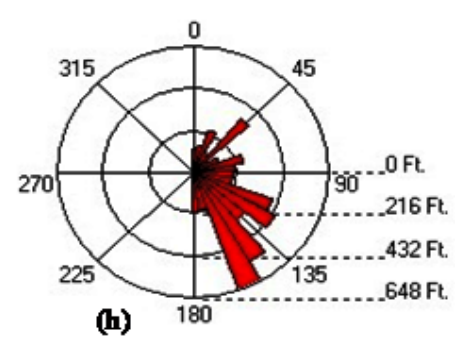

(h)
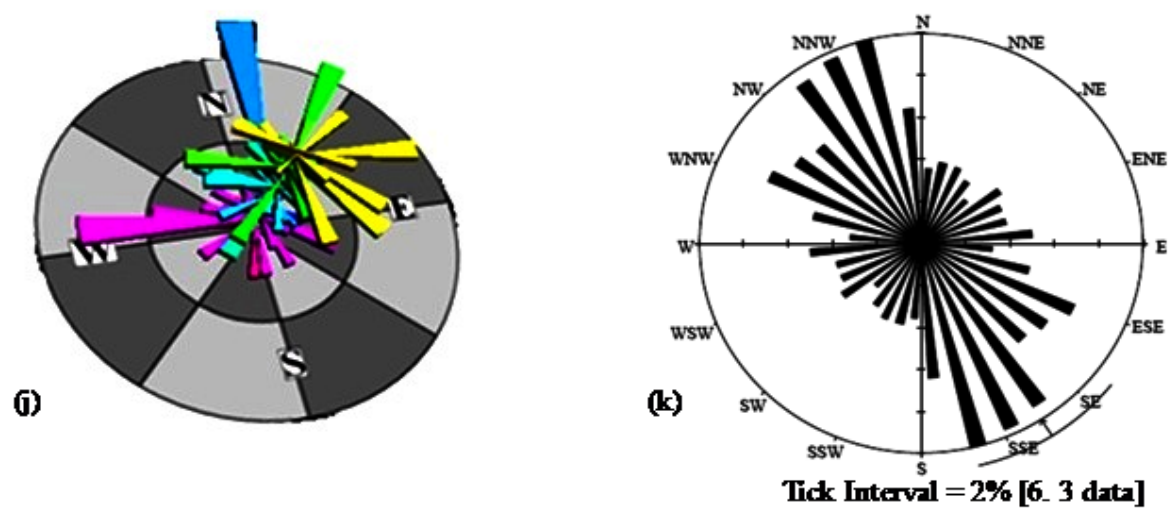

Fig.10. Rose diagrams showing passage orientations of cave (a) Anak Tempurung, (b) Datok, (c) Kanthan, (d) Kepayang, (e) Lyang Lyang, (f) Masoora, (g) Sam Poh Tong, (h) Tempurung, (i) Paradise valley, (j) Kandu (3D), and (k) Overall passage trend

In the same area, on the wall of a precipitous hill which surround a doline, similar fracture orientations were observed, and Figure $12 \mathrm{~b}$ and $\mathrm{c}$ indicate their relative age of occurrence as the NNW-SSE oriented fracture appears to be displaced by later NE-SW trending fracture. On a large scale, further away in the same hill, the cross-cutting relationship of the fractures is quite conspicuous (Fig.13) and depicts their relative age of formation.

\section{Structural Setting}

Satellite images are indispensable to identify lineaments and get an insight into regional or local structures. The high resolution Spot image employed profoundly facilitated the ease of recognising and extracting lineaments manually. The remnant hills are quite small compared to the broad valley, and the lineaments extracted from these hills appear insignificant when they are plotted together (Fig. 6a). However, merging all the fractures extracted from the individual hills enabled to see the prominent trend, in the whole valley, which might have been formed before the commencement of karstification of the expansive limestone bedrock. Figure 11 clearly indicates the distribution of the lineaments in each hill and their respective orientations from which the overall trend is made. All lineaments above $60 \mathrm{~m}$ were extracted from the vestige hills, taking the small size of the hills into account, and the longest fractures appear to be $1.2 \mathrm{~km}$ long. Although they are short in length and considered as joints, they can be part of the fault, as their continuity, in many places, appears to be interrupted by the occurrence of dolines (for example, Fig. 4b), and the rivers that traverse through the hills and ultimately made them isolated. This can be further attested by the presence of fault scarps (Fig. 14), at the southern part of the study area, which can be part of the extensive fault system. Hence, the observed fracture traces of the same group, all over the valley, may possibly be of concomitant origin since the karst features, aligned along the direction of these structures, with little doubt, occurred via the pre-existing extensive fault.

The structures observed and extracted from the remnant hills look utterly complex, and this may be attributed to the different phases of tectonics or various set of stress system, although there may be a possibility that some minor faults might have feathered off at acute angles from the main fault as a result of wrenching of the rock. Though a detail structural study 
was not conducted to prove the influence of the different stress system, the intensely karstified landform and a comparison of the lineaments extracted from the remnant hills with that of the regional structures attest to the possible impact of different phases of tectonics in the formation of the geological structures in the Kinta Valley. It is difficult to know the exact period of occurrence of the various structures in the area; nonetheless, identifying the major lineament trends in the carbonate and granite hills enables to comprehend their relative age of formation, particularly by comparing them with the main regional faults.

The Peninsula has a NNW-SSE elongated shape and the shape is controlled by the regional structures (Shuib, 2009). According to this author, the prominent NNW-SSE trending faults are common to the north and south of the Kinta Valley; these faults are believed to be the result of three deformational phases that occurred in the Late Triassic to Early Jurassic, Upper Cretaceous and Tertiary periods. Like the regional structures, the principal NNWSSE lineament trend, observed in the Kinta Valley, is superimposed by structures striking in five different trends, and the similarity of these structural trends with the regional ones indicates that the geological elements in the Kinta karst region may have been formed by the tectonic processes which gave rise to the regional structures, not the consequence of local processes. Hence, the NNW-SSE main structural trend of the peninsula, most likely, controlled the karst landform of the study area

\section{Relation between the different fracture sets}

In different hills, the fracture traces appear to be crossing each other, and in some places are marked by dolines and sinkholes. On a large scale, Figure $12 \mathrm{a}$ depicts this phenomenon. The intersecting nature of the fracture traces could be a consequence of the multi-phase episodes of fracturing. Although it is difficult to distinguish the relative age of the lineaments extracted from the image, observations during ground truthing of the area reveals that the prominent shear fracture oriented along the NNW-SSE appears relatively older than the NE-SW one (Fig. 12c), as the cross-cutting relationship clearly depicts. The orientation of this later structure corresponds to the prominent orientation of the lineaments extracted from the adjoining Main Range granite (Fig. 6b); this may be related to their concurrent origin, which in turn may lead to infer that their formation is successive to the principal NNW-SSE trending faults.

The close-up of the three fracture sets in Figure 13, observed in a vertically dipping bed in Gunung Datok, illustrates their relative ages. The micro fracture III is not discernible in the picture, but quite noticeable at the
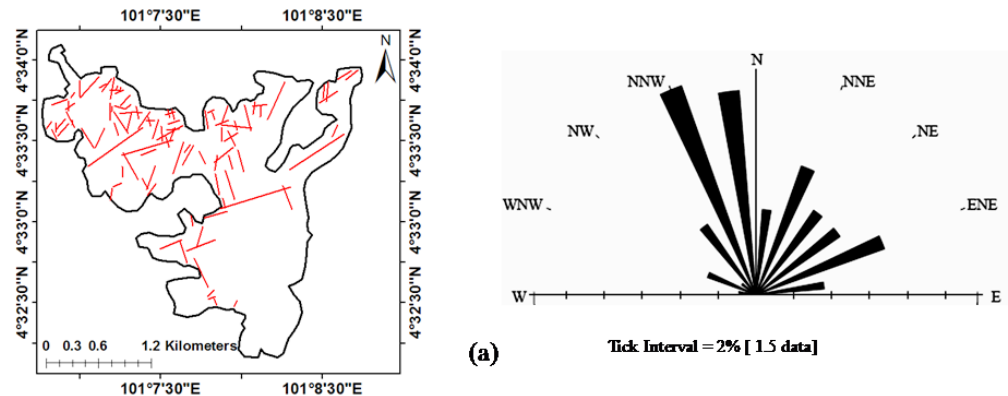

(a)
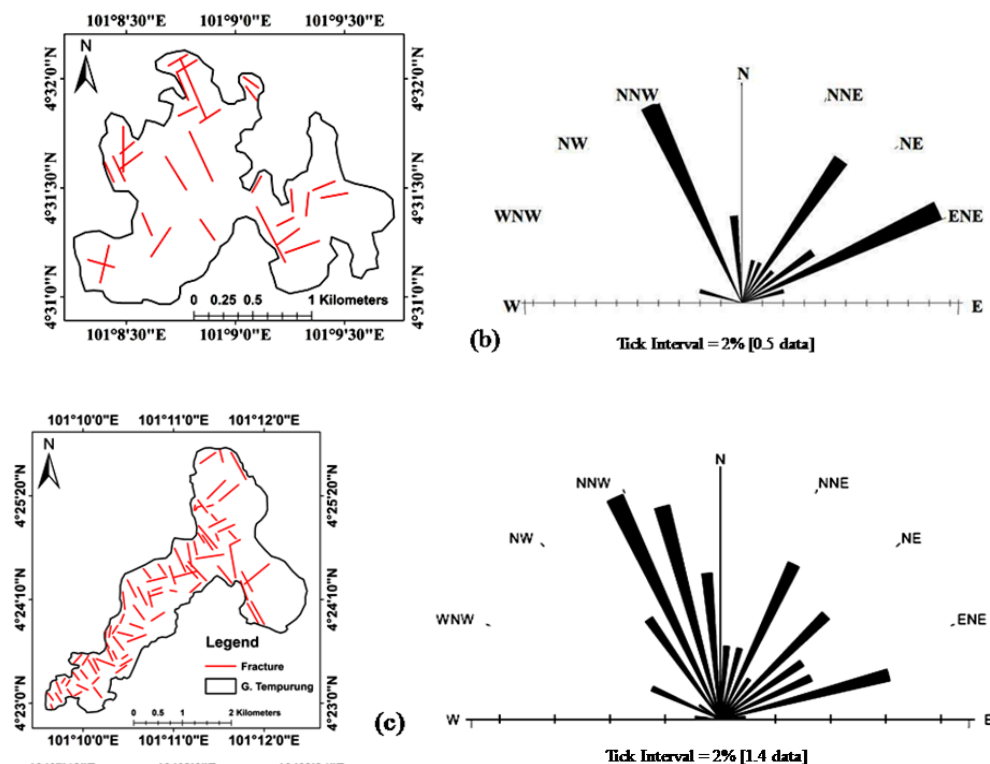

(c)
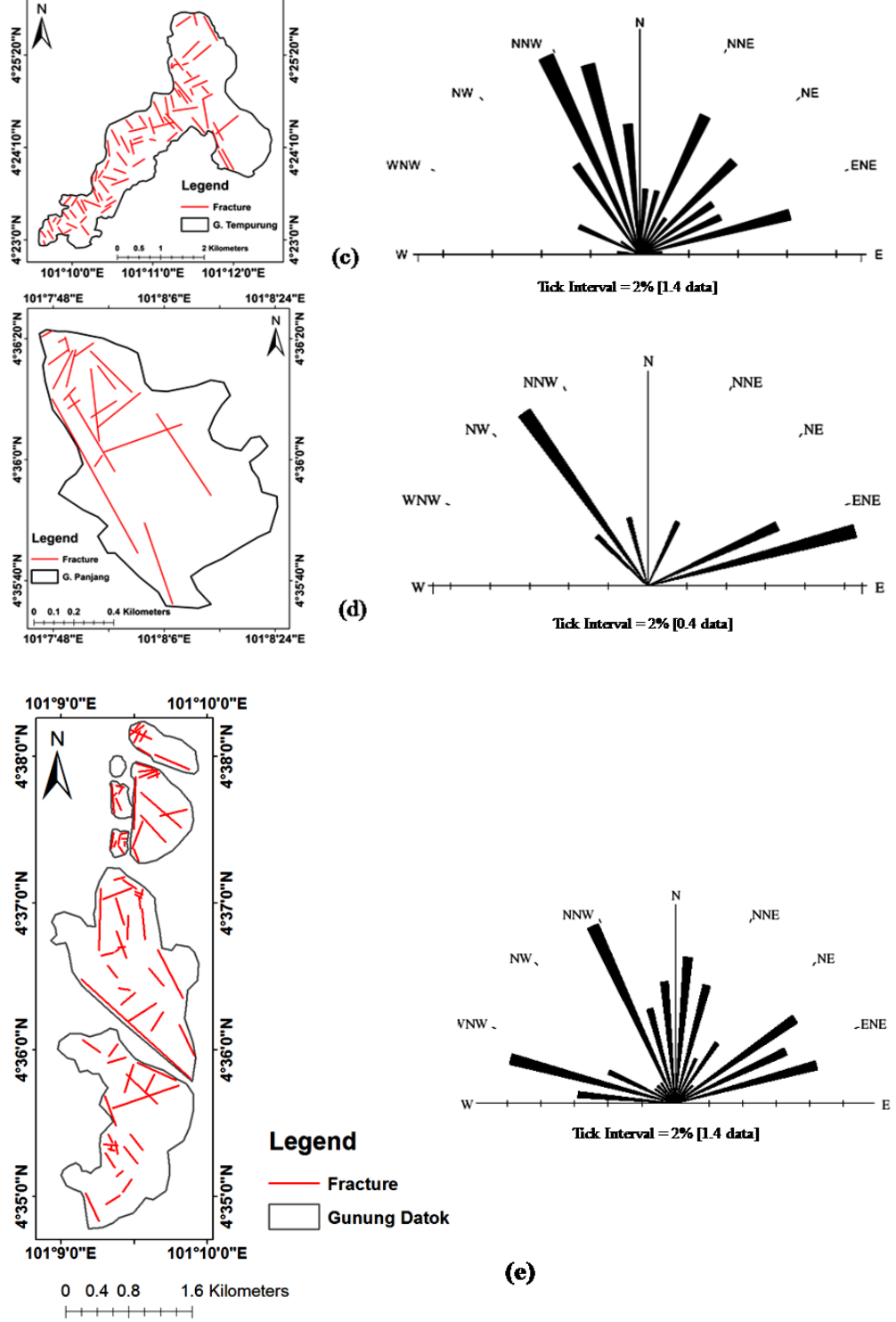

Fig.11. Distribution of lineaments in the vestige hills and their respective orientations shown by the associated rose diagrams for (a) Gunung Rapat, (b) Gunung Lanno, (c) Gunung Tempurung, (d) Gunung Panjang, and (e) Gunung Datok 


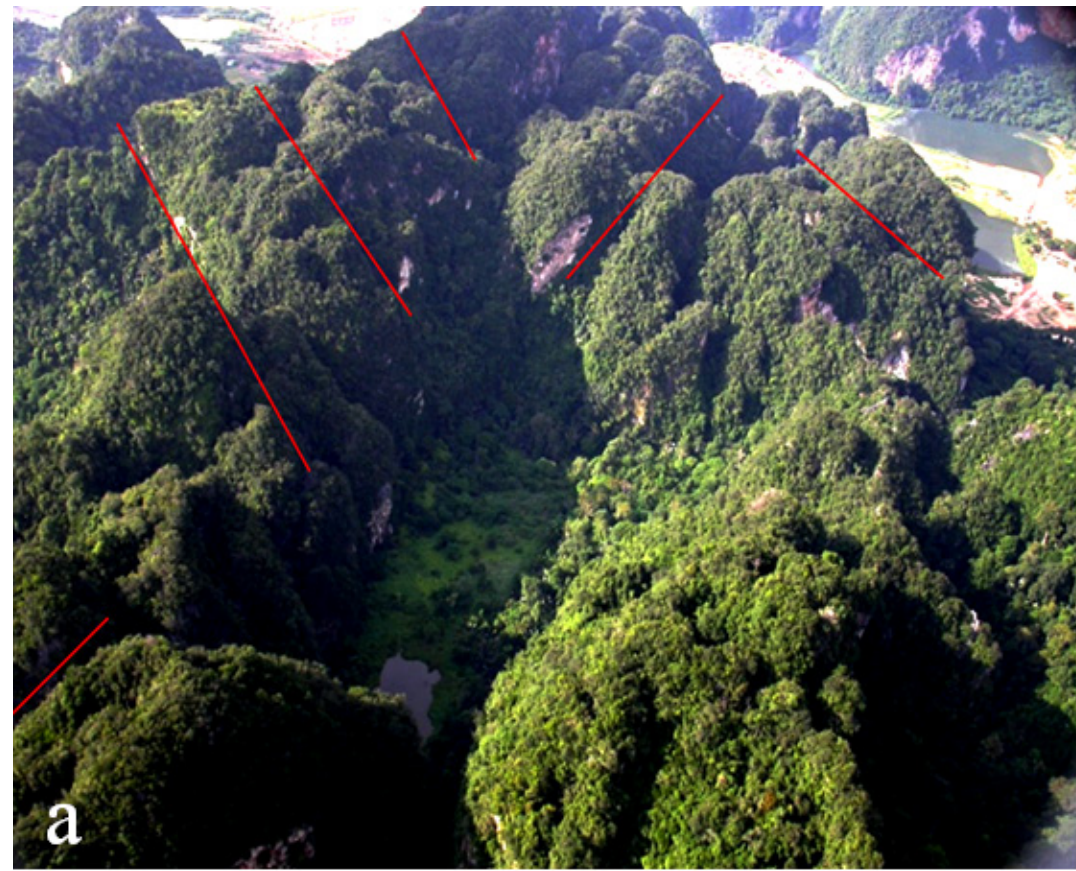

Fig.12. (a) Fractures noticeable on the hill give clues for their influence in the development of sinkholes and dolines, (b) and (C) Close-up of fractures inside a doline, in Gunung Datok, denoting their relative age relationship as the NNW-SSE oriented fracture is displaced by the later NE-SW one.

location where it is taken. Although fractures II and III are parallel, they are not coeval in origin as II evidently depicts calcite infill. If they were of the same origin or III was formed earlier, one might expect calcite infill in III too; hence, II is older than III despite their appearance as the same fracture set. The fracture I is displaced by II and III, and the offset of this fracture is not in the same sense, but it does not mean that it is younger than them or of different fractures which abutted in II and III at different time. This is because III occurred at a later stage and it displaced I, which is already displaced by II, and made it to shift in an opposite sense; this in turn indicates that the occurrence of I is prior to II and III. IV intersects the others without any displacement; therefore it can be inferred that it is the last to occur. Thus, chronologically I to IV is from the oldest to the youngest. The micro fractures further substantiate the aforementioned inference that all fractures did not occur concurrently and there is, most likely, a relative time gap among them.

\section{HYDROLOGY}

Some of the caves such as Gua Tempurung (Fig. 9a), Gua Anak Tempurung (Fig. 9b), and Gua Kanthan (Fig. 5a) are still being denuded by allogenic waters. Relict karstic caves, whose entrances are situated at the base and in the wall of the steepest hills, above the valley floor, are common in the area, and paleoflow indicators, such as scallop features (for example Fig. 3e) are quite noticeable in their passage walls. These features plainly indicate the past water flow direction towards the base levels, and this may lead to infer that the caves may have

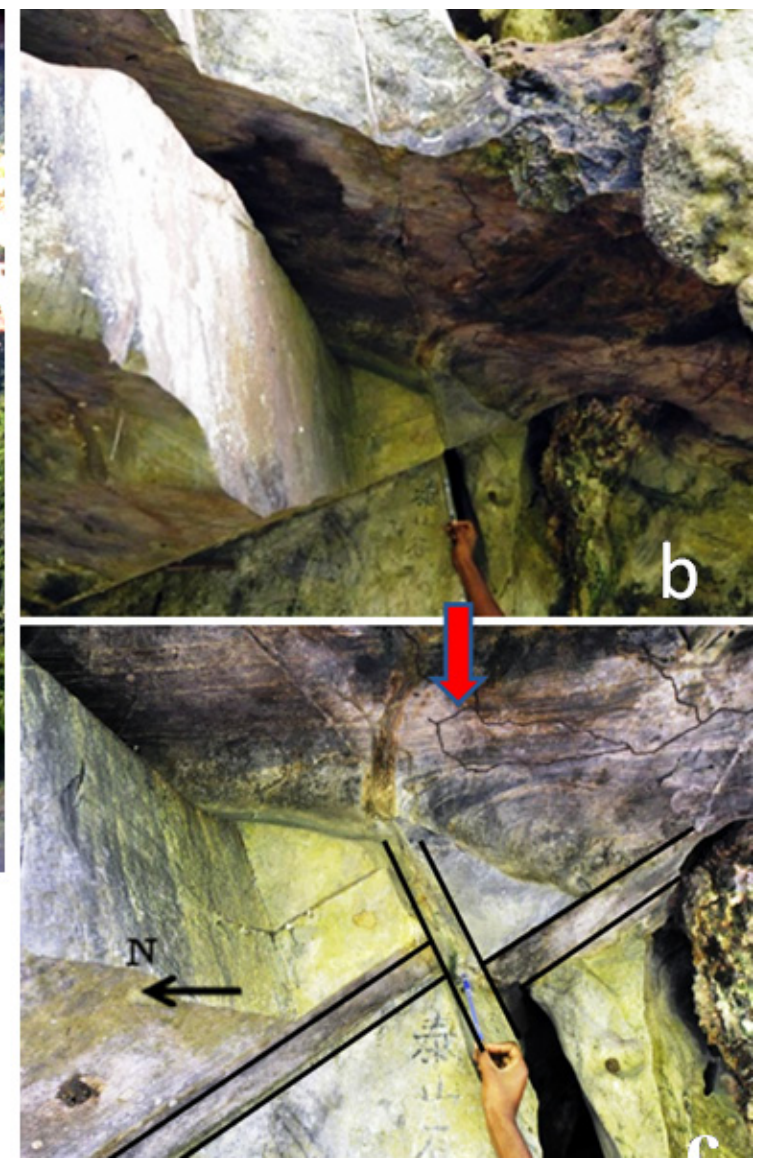

been formed or modified by the current hydrologic system. Moreover, some caves such as Gua Masoora and Gua Lyang Lyang, indicate subsurface water residing underneath their passage which may attest to the existence of the water at a higher level before recession. Rivers passing in between and through the hills, springs emerging from the hills, pools of water inside the caves which possibly are connected to other caves via subsurface channels, river crossing dolines and passing through caverns are a common hydrologic phenomenon observed in the Kinta Valley karst region.

The geometry of fluvial networks is an important morphostructural indicator and their trend alignment with the orientations of geological structures indicates tectonic control of drainage networks (Beneduce et al., 2004; Garcia \& Herail, 2005; Hodgkinson et al., 2006; Ribolini \& Spagnolo, 2008). The similarity of the rivers and their tributaries pattern in the Kinta Valley and on the Main Range granite, and their parallel SW flow clearly indicate the effect of NNESSW to NE-SW trending faults, and similarly these faults are responsible for the modification of the karstification pattern. According to Prost (2001), streams aligned across drainage divides, or on both sides of a major drainage suggest fault control, and barbed drainage and long, linear valley also suggest faulting. The river caves in the Kinta Valley, Gua Tempurung and Gua Anak Tempurung, are prime examples of the barbed nature of cave passages morphology, and this pattern may be attributed to the multiphase tectonic deformations as indicated by the lineaments extracted from the hill. 


\section{Structures favouring karst development}

The analyses of passage orientations reveal that the main trend of caves in different hills appears to be in the NNW-SSE direction. The rose diagram (Fig. 10k) indicates the caves passage trends when all survey data, from different caves, are plotted together. These survey data are merged together after excluding short cave passages which are thought to be non representative; thus, the overall trend enabled to comprehend the direction of the predominant passage trend which presumably was formed along the main fracture zone. Similarly, plotting all survey data together enabled to visualize the similarity of the overall cave passage trend with the general lineament trend extracted from the vestige hills.

Besides plotting all data together, to denote the similarity of the geological structures and cave passage trends, observation of linear cave passages which clearly indicate their development following fracture traces are present in the northern (example Fig. 5a) and southern (example Fig. 5b) part of the study area, which are about $20 \mathrm{~km}$ apart. And it is believed that these caves may attest to the same geologic structures to have influenced the whole area and controlled the development of karst features.

Where the effect of fracturing is paramount, caves passage development is inevitable via the failure zones, and the caves passage geometry in the study area evidently illustrates their formation following the original fracture trace without subsequent fracturing effect related to its gradual development. Some karst features, such as Kandu cave (Fig. 4a), are a clear reflection of multi-fracturing phenomenon, as the circular passage suggests, rather than being the consequence of fracturing related to their development. The presence of fractures oriented in different directions is the reason for the occurrence of sinuous (Fig. 9a and b) or circular (Fig. 4a) cave passages as the flow path favourably takes place along the different directions, following lower resistance, to make up the conduit system. Gunung Tempurung is a good example to illustrate the fracturing event and subsequent karst formations. This hill is shattered by fractures (Fig. 11c) and characterized by a number of dolines and convoluted cave passages which attest to the effect of multi-fracturing. Although the Gua
Tempurung map indicates only the river path, in some places, all the way from the entrance to the outlet, there are big chambers which may have formed at the point where various fractures intersect. And during surveying it is noted that such chambers are located where the river path diverts. Thus, the effect of multifracturing, which formed the complex structures, was responsible for the occurrence of subsurface drainage systems which are associated with the development of various karst features in the Kinta Valley.

The mature karst in the Kinta Valley can be categorised as 'Stripe Karst', an extreme case of contact karst (Lauritzen, 2001). According to him, originally flat lying strata may end up as an extremely elongated outcrop which could almost always be a product of tectonic and/or erosional modification; therefore, it is believed that orogenic tectonism is the most common and effective process to create stripe karst. The limestone in the Kinta Valley predates the adjoining granites (Ingham \& Bradford, 1960; Hutchison, 2009), and possibly the karstification process became so intense after the occurrence of the granite as its gradual uplifting was accompanied by faulting (Madon, 1999). The uplifted surface enhanced the mechanical denudational process and the associated faulting created conducive pathways that facilitated solute attack. Thus, the existing karst features in the area are a product of tectonic and denudational processes.

Tectonic elements, such as fractures, faults and joint patterns can serve as conduits for transport and storage of groundwater, and play a decisive role in the karstification process. Although various factors, such as climate, lithology and vegetation are responsible for karst formation, the influence of tectonic structures can be considered as a crucial factor for the formation of the extant karst morphology in the Kinta Valley. Most of the karst features appear to align along a certain trend indicating their formation following or via structures trending in the same direction.

The Kinta Valley karst features are utterly controlled by faults, mainly oriented in the NNW$\mathrm{SSE}$, which is also the prominent orientation of the regional structures, and the onset of karstification in this region may have taken place after the formation of these faults. According to Hutchison (2009), in
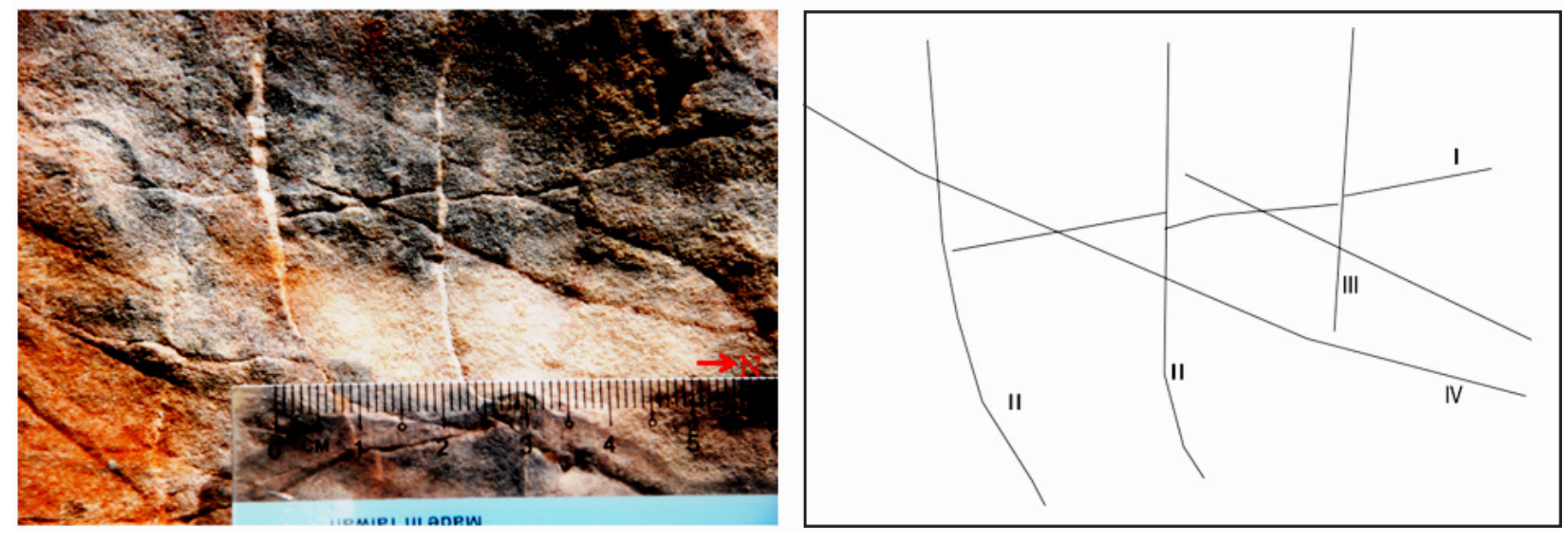

Fig.13. Interaction of fracture sets and their cross-cutting relationship 


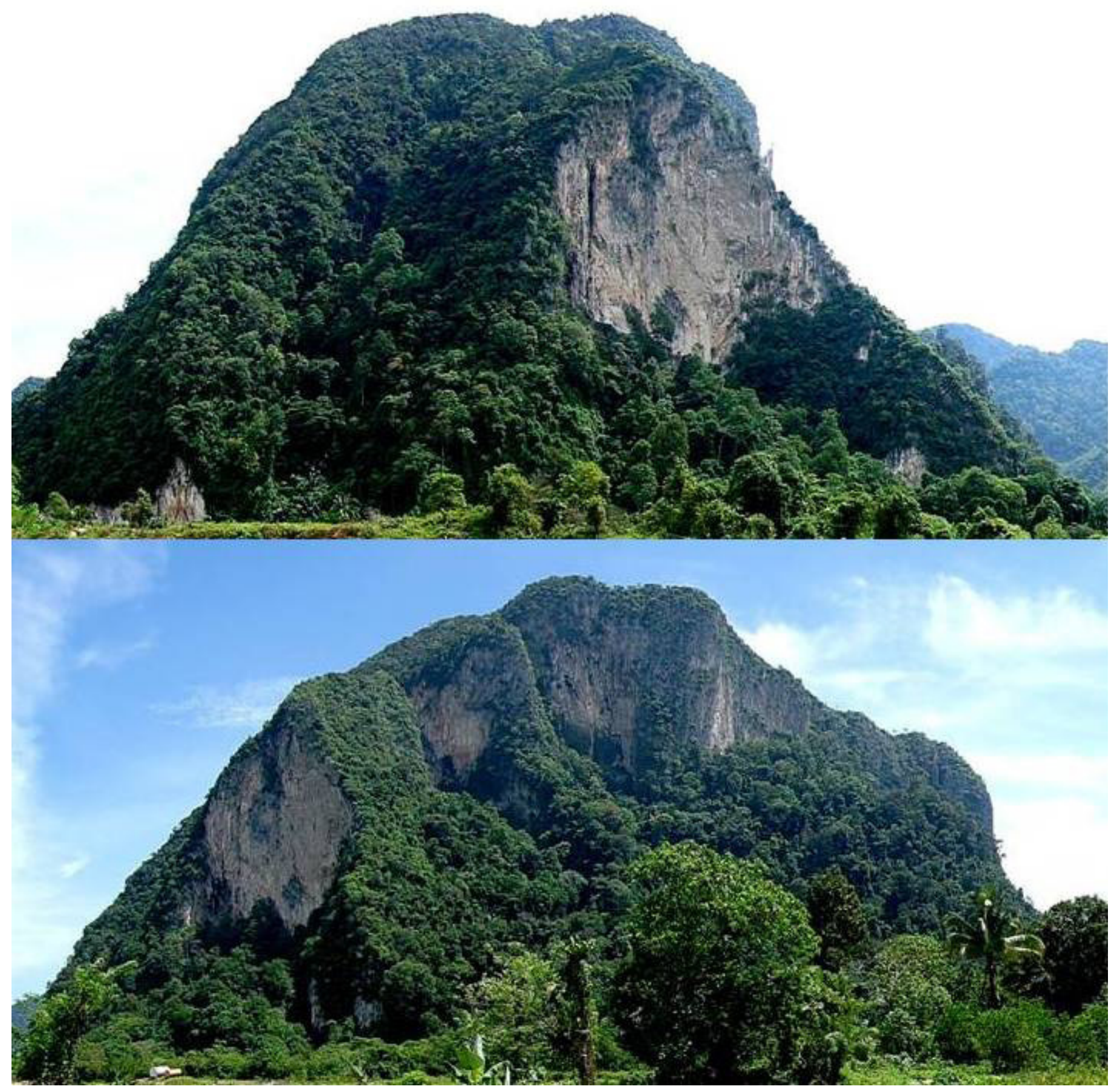

Fig.14. Depicting fault scarp as it appears in the side and front view of an isolated hill situated in the southern part of the study area

the Late Triassic to Jurassic period emplacement of the Main Range Granite took place; at or late stage of this emplacement the development of NNW-SSE to N-S strike-slip faults were followed. Considering the fact that geological structures in the Kinta Valley are related to the regional structures and the NNWSSE faults in the area are the principal lineaments, as evidenced by the cave passage orientations, lineament analyses and ground truthing, the occurrence of the main faults, which controlled the karst formation, can be considered to date back to the Lower Cretaceous period. Taking the significant influence of the geological structures in the area in to account and considering that they are prerequisites for the occurrence of karst, it would be possible to infer the Lower Cretaceous period, most likely, marks the commencement of karst formation in the area.
In the study area, the crystalline limestone appears to dip vertically where it is situated close to the granite, and the angle of dip decreases away from the contact zone. Such dip angle variation of the bedrock might have taken place as a consequence of the gradual uplifting of the adjoining granite; however, it needs detailed structural analysis so as to provide a comprehensive description, which is not part of this work. Nonetheless, caves observed near the contact zone might have occurred after the bedrock has subjected to dip at a considerable angle, for example the vertically grown stalactite and column inside a cave, formed in an almost vertically dipping bed (Fig. 15a), plainly attest their later occurrence. This is because, if there was any movement after the speleothems formation, they would appear tilting away from the vertical 
position by the same angle the whole rock mass dips. However, still there is a possibility that we cannot infer the dipping of the bed to predate the cave formation if the age of the speleothems is too young. Further inside this cave, whose entrance is located about $30 \mathrm{~m}$ above the base of the hill, horizontally layered cave infilling sediment (Fig. 15b) is noticeable. In this case, geologically speaking, the deposition may not be recent as it is located about $30 \mathrm{~m}$ above the surface, and the agent responsible for its deposition might have receded quite a long time ago. Hence, the vertical bed and the horizontally layered sediment may illustrate the formation of the cave to be predated by the dipping of the bedrock. However, there may be a possibility that the cave formation predates the dipping if the incipient cave development had occurred before any vertical movement took place. The intrinsic part of this observation leads us to the question 'is it the dipping of the bed predating the fracture formation or vice versa?' Scrutinizing the tectonic history of the area may unravel their relative age of occurrence and will further clarify the aforementioned inferences.

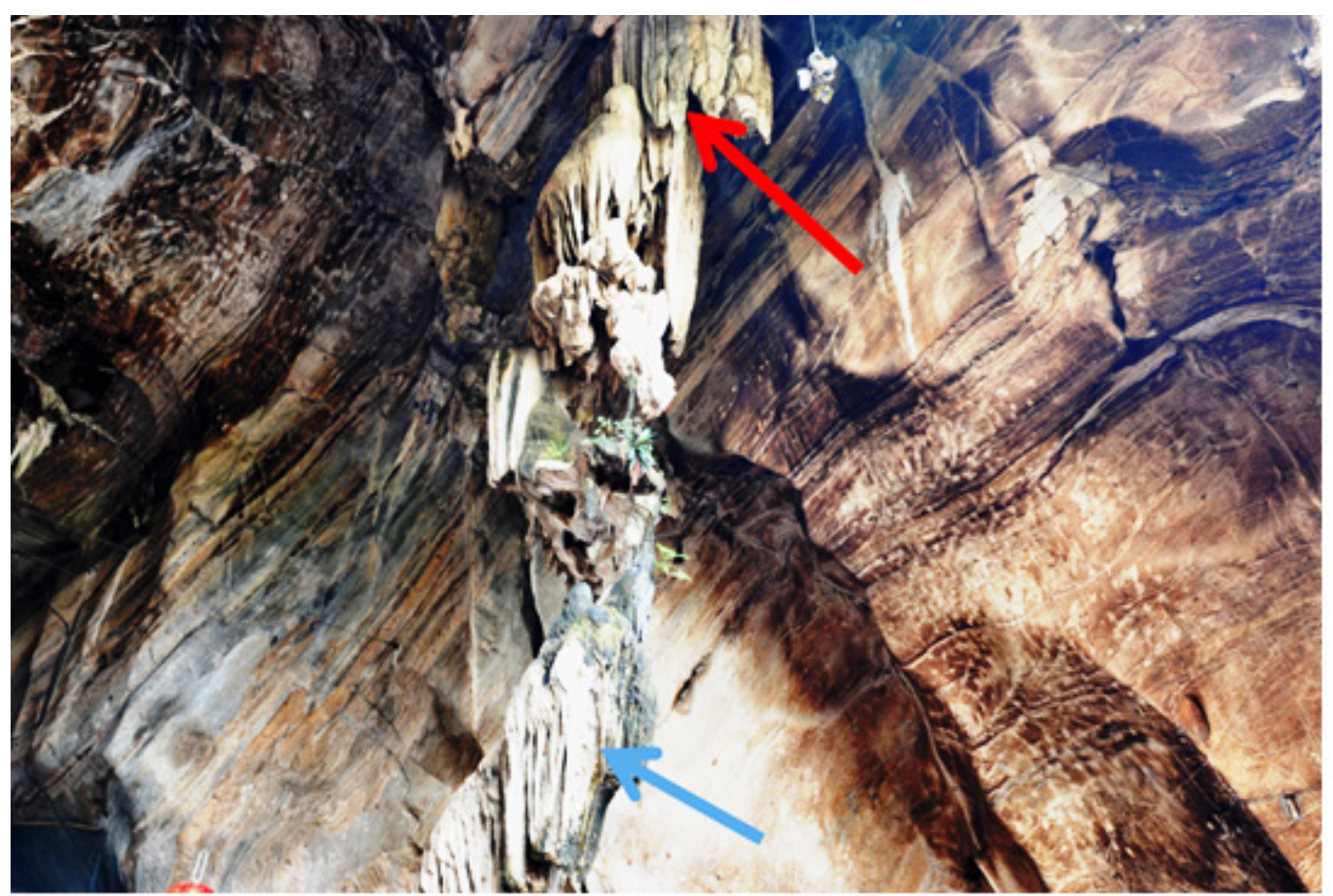

Fig.15. (a) Depicting vertically grown stalactite (red arrow) and column (blue arrow) inside a cave formed in a vertically dipping bed, (b) further inside the cave, the green arrow shows the dipping bed and the red arrow indicates the horizontally layered sediment

\section{(a)}

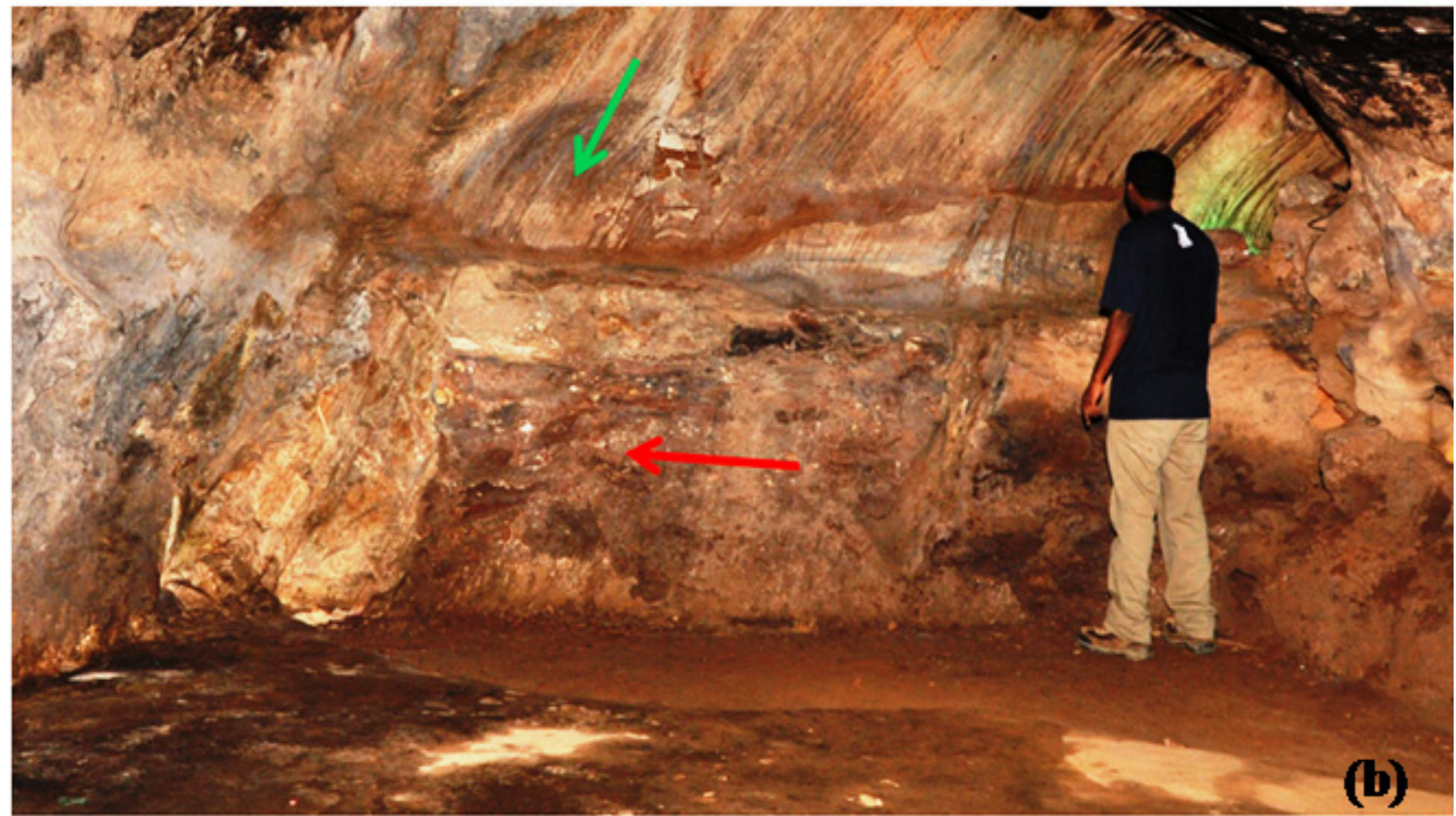




\section{CONCLUSION}

The influence of geological structures was paramount in the development of the extant karst landscape of the Kinta Valley. In order to unravel this influence, lineament analyses have been undertaken using Spot image of $2.5 \mathrm{~m}$ resolution. Six trends of lineaments were extracted from the remnant hills and their prominent orientation appears to strike in a NNW-SSE trend. This orientation is also found to be the principal trend for the caves passage as obtained from the individual caves situated all over the valley. It is inferred that such similarity clearly indicates the formation of the caves to be mainly controlled by the geological structures. The fault striking NNW-SSE is considered to be the first structure to affect the originally expansive limestone bedrock and karstification in the area is believed to have commenced and intensified after its formation, and modified by the later structures that superimposed on it. Besides the similarity of the main caves passage orientation and the prominent fractures trend, observed cross cutting relationship of fractures plainly illustrate the pre-existence of the NNWSSE trending faults. This further substantiates the inference drawn for the main NNW-SSE faults to be the oldest and most likely the onset of karstification to take place via them. The effect of multi-fracturing made the Kinta Valley to be structurally complex, and this is evidenced by the karst features, such as circular caves passage morphology (for example in Gua Kandu) and sinuous cave passages (in the case of caves in Gunung Tempurung), which developed following fractures oriented in different directions.

\section{ACKNOWLEDGEMENTS}

This work was supported by STIRF fund from Universiti Teknologi PETRONAS, shell grant to Universiti Teknologi PETRONAS and partially from the International Association of Sedimentologists (IAS). The satellite image of the study area was kindly provided by Malaysian Remote Sensing Agency (MRSA). The Authors would like to thank Dr. Rod Holcombe for the free access of GEOrient software, and Malaysian Karst Society (MKS) members: Robert Percival, Cheang Kum Seng and Bernard Lee, for their help during cave surveying.

\section{REFERENCES}

Arlegui L.E. \& Soriano M.A., 1998 - Characterizing lineaments from satellite images and field studies in the central Ebro basin (NE Spain). International Journal of Remote Sensing, 19: 3169-3185. http://dx.doi.org/10.1080/014311698214244

Becker J. J., Sandwell D. T., Smith W. H. F., Braud J., Binder B., Depner J., Fabre D., Factor J., Ingalls S., Kim S-H, Ladner R., Marks K., Nelson S., Pharaoh A., Trimmer R., Von Rosenberg J., Wallace G. \& Weatherall P., 2009 - Global Bathymetry and Elevation Data at 30 Arc Seconds Resolution: SRTM30 PLUS. Marine Geodesy, : 355-371. http://dx.doi.org/10.1080/01490410903297766
Beneduce P., Festa V., Francioso R., Schiattarrela M. \& Tropeano M., 2004 - Conflicting drainage patterns in the Matera Horst Area, Southern Italy. Physics and Chemistry of the Earth, 29: 717-724.

Bosák P., 2003 - Karst processes from the beginning to the end: How can they be dated? Speleogenesis and Evolution of Karst Aquifers, : 1-24.

Deike R.G., 1969 - Relations of jointing to orientation of solution cavities in limestone of central Pennsylvania. American Journal of Science, 267: 1230-1248. http:/ /dx.doi.org/10.2475/ajs.267.10.1230

Deike H.G., 1989 - Fracture controls on conduit development. In: White W. B. \& White E. L. (Eds.), Karst Hydrology: Concepts from the Mammoth Cave Area. Van Nostrand Reinhold, NY: 259-291.

Faulkner T., 2006 - Tectonic Inception in Caledonide Marbles. Acta Carsologica, : 7-21.

Florea L.J., 2002 - Detection of Iapetan Rifting (Rome Trough Tectonism) by Quaternary Karstification: Pulaski County, Kentucky. In: Martin J., Wicks C. \& Sasowsky I. (Eds.), Karst Frontiers. Karst Waters Institute: 192-204.

Ford D. \& Williams P., 2007 - Karst Hydrogeology and Geomorphology. John Wiley and Sons, Chichester, $562 \mathrm{p}$.

Galanos I. \& Rokos D., 2006 - A statistical approach in investigating the hydrogeological significance of remotely sensed lineaments in the crystalline mountainous terrain of the island of Naxos, Greece. Hydrogeology Journal, 14: 1569-1581. http://dx.doi.org/10.1007/s 10040-006-0043-2

Garcia M. \& Herail G., 2005 - Fault-related folding, drainage network evolution and valley incision during the Neogene in the Andean Precordillera of Northern Chile. Geomorphology, : 279-300. http://dx.doi.org/10.1016/j.geomorph.2004.09.007

Geyer E., Jeutter P., Kogler S., Price L., Segl J., Schmidt F., Steiner H., Wolf A., Yian S., Kusch H. \& Örtel A., 2005 - Speleological Expedition Gunung Lanno. Verein für Höhlenkunde in Obersteier, BadMitterndorf, Austria, 240 p.

Ghani A.A., 2009 - Plutonism. In: Hutchison C.S. \& Tan D.N.K. (Eds.), Geology of Peninsular Malaysia. Geological Society of Malaysia: 211-232.

Gillieson D., 2005 - Karst in Southeast Asia. In: Gupta A. (Ed.), The Physical Geography of Southeast Asia. Oxford University Press: 157-176.

Glazek J., 1989 -Tectonic conditions for karst origin and preservation. In: Bosak P., Ford D.C., Glazek J. \& Horacek I. (Eds.), Paleokarst. A Systematic and Regional Review. Amsterdam-Praha: ElsevierAcademia: 569-575.

Henderson D. B., Ferrill D. A. \& Clarke K. C., 1996 Mapping Geological Faults Using Image Processing Techniques Applied to Hill-Shaded Digital Elevation Models. IEEE, 240-245.

Hodgkinson J.H., McLoughlin S. \& Cox M., 2006 - The influence of geological fabric and scale on drainage pattern analysis in a catchment of metamorphic terrain: Laceys Creek, southeast Queenland, Australia. Geomorphology, 81: 394-407. http://dx.doi.org/10.1016/j.geomorph.2006.04.019 
Hung L.Q., Dinh N.Q., Batelaan O., Tam V.T. \& Lagrou D., 2002 - Remote sensing and GIS based analysis of cave development in the Suoimuoi catchment (SON LA-NW Vietnam). Journal of Cave and Karst Studies, : 23-33.

Hutchison C.S., 1966 - Dating Tectonism in the Indosinian-Thai-Malayan Orogen by Thermoluminescence. Geological Society of America Bulletin, 79: 375-386. http://dx.doi.org/10.1130/0016-7606(1968) 79[375:DTITIO]2.0.CO;2

Hutchison C.S., 2007- Geological Evolution of SouthEast Asia. Geological Society of Malaysia, 433 p.

Hutchison C.S., 2009- Tectonic Evolution. In: Hutchison C.S. \& Tan D.N.K. (Eds.), Geology of Peninsular Malaysia. Geological Society of Malaysia: 309330.

Ingham F.T. \& Bradford E.F., 1960 - The Geology and Mineral Resources of the Kinta Valley, Perak. Federation of Malaya Geological Survey District Memoir , 347p.

Jameson R.A., 2005 - Identification and analysis of early flow paths in branchwork caves in West Virginia, USA. Geological Society of America Special Papers, 404: 23-30.

Koike K., Nagano S \& Kawaba K., 1998 - Constraction and Analysis of Interpreted Fracture Planes Through Combination of Satellite-Image Derived Lineaments and Digital Elevation Model Data. Computers and Geosciences, : 573-583. http://dx.doi.org/10.1016/S0098-3004(98)00021-1

Lauritzen S. E., 2001 - Marble stripe karst of the Scandinavian Caledonides: An end-member in the contact karst Spectrum. Acta Carsologica, 30(2): 4779.

Leech D.P., Treloar P.J., Lucas N.S. \& Grocott J., 2003 - Landsat TM analysis of fracture patterns: a case study from the Coastal Cordillera of northern Chile. International Journal of Remote Sensing, : 3709-3726.

http://dx.doi.org/10.1080/0143116031000102520

Lillesand T.M., Kiefer R.W., Chipman J.W., 2008 - Remote Sensing and Image Interpretation. John Willey \& Sons, $756 \mathrm{p}$.

Lowe D.J., 1999 - Why and how are caves "organized": does the past offer a key to the present. Acta Carsologica, 28/2: 121-144.

Madon M.B.H., 1999 - Plate Tectonic Elements and Evolution of Southeast Asia. In: Petronas Company (Ed.), The Petroleum Geology and Resources of Malaysia. The Petroliam Nasional Berhad (Petronas), Kuala Lumpur: 59-76.

Mah A., Taylor G.R., Lennox P. \& Balia L., 1995 Lineament Analysis of Landsat Thematic Mapper Images, Northern Territory, Australia. Photogrammetric Engineering and Remote Sensing, : 761773.
Metcalfe I., 2000 - The Bentong-Raub Suture Zone. Journal of Asian Earth Sciences, 18: 691-712. http://dx.doi.org/10.1016/S1367-9120(00)00043-2

Nama E.E., 2004 - Lineament detection on Mount Cameroon during the 1999 volcanic eruptions using Landsat ETM. International Journal of Remote Sensing, : 501-510. http://dx.doi.org/10.1080/0143116031000102557

Palmer A.N., 1975 - The Origin of Maze Caves. The NSS Bulletin, 37: 56-76.

Palmer A. N., 1989 - Fracture controls on conduit development. In: White W. B. \& White E. L. (Eds.), Karst Hydrology: Concepts from the Mammoth Cave Area. Van Nostrand Reinhold, NY: 293-316.

Peng L.C., 2009 - Paleozoic Stratigraphy. In: Hutchison C.S. \& Tan D.N.K. (Eds.), Geology of Peninsular Malaysia. Geological Society of Malaysia: 55-86.

Pierson B.J., Askury A.K., Chow W.S. \& Zuhar Z.T.H., 2009 - The Limestone hills of the Kinta Valley: a part of Malaysian's geological heritage worth preserving. EAGE, : 97-100.

Prost G.L., 2001 - Remote sensing for geologists: a guide to image interpretation. Lausanne: Gordon and Breach Science, 326 p.

Reeder P., Robert B. \& Alt E., 1996 - Karstification on the Northern Vaca Plateau, Belize. Journal of Cave and Karst Studies, 58: 121-130.

Ribolini A. \& Spagnolo M., 2008 - Drainage network geometry versus tectonics in the Argentera Massif (French-Italian Alps). Geomorphology, : 253-266. http://dx.doi.org/10.1016/j.geomorph.2007.02.016

Sander P., Minor T.B. \& Chesley M.M., 1997 - Groundwater exploration based on lineament analysis and reproducibility tests. Ground Water, 35: 888-894. http://dx.doi.org/10.1111/j.1745-6584.1997.tb00157.x

Shuib M.K., 2009 - Major Faults. In: Hutchison C.S. \& Tan D.N.K. (Eds.), Geology of Peninsular Malaysia. Geological Society of Malaysia: 249-269.

Spencer E.W., 1988 - Introduction to the structure of the earth. McGraw-Hill Inc., $551 \mathrm{p}$.

Süzen M.L. \& Toprak V., 1998 - Filtering of Satellite Images in Geological Lineament Analyses: An Application to a Fault Zone in Central Turkey. International Journal of Remote Sensing, 19: 1101-1124. http://dx.doi.org/10.1080/014311698215621

Tam V.T., De Smedt F., Batelaan O. \& Dassargues A., 2004 - Study on the relationship between lineaments and boreholes specific capacity in a fractured and karstified limestone area in Vietnam. Hydrogeology Journal, 12: 662-673. http://dx.doi.org/10.1007/s10040-004-0329-1

White W.B. \& Deike H.G., 1989 - Hydraulic geometry of cave passages. In: White W. B. \& White E. L. (Eds.), Karst Hydrology: Concepts from the Mammoth Cave Area. Van Nostrand Reinhold, NY: 223-256. 